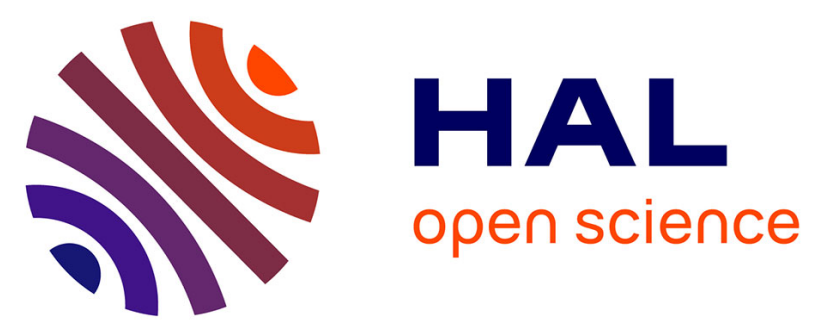

\title{
From ductile to brittle, late- to post-orogenic evolution of the Betic Cordillera: Structural insights from the northeastern Internal zones
}

\author{
Romain Augier, Laurent Jolivet, Damien Do Couto, François Negro
}

\section{- To cite this version:}

Romain Augier, Laurent Jolivet, Damien Do Couto, François Negro. From ductile to brittle, late- to post-orogenic evolution of the Betic Cordillera: Structural insights from the northeastern Internal zones. Bulletin de la Société Géologique de France, 2013, 184 (4-5), pp.405-425. 10.2113/gssgfbull.184.4-5.405 . insu-00868910

\section{HAL Id: insu-00868910 https://hal-insu.archives-ouvertes.fr/insu-00868910}

Submitted on 8 Feb 2017

HAL is a multi-disciplinary open access archive for the deposit and dissemination of scientific research documents, whether they are published or not. The documents may come from teaching and research institutions in France or abroad, or from public or private research centers.
L'archive ouverte pluridisciplinaire HAL, est destinée au dépôt et à la diffusion de documents scientifiques de niveau recherche, publiés ou non, émanant des établissements d'enseignement et de recherche français ou étrangers, des laboratoires publics ou privés. 


\title{
From ductile to brittle, late- to post-orogenic evolution of the Betic Cordillera: Structural insights from the northeastern Internal zones
}

\author{
Romain AUGIER ${ }^{1,2,3}$, LAURent JOLIVET ${ }^{1,2,3}$, DAmien DO COUTO ${ }^{4,5}$ and FrançOIS NEGRO ${ }^{6}$
}

\begin{abstract}
Keywords. - Exhumation, Extension, Palaeostresses, Inversion tectonics, Salinity crises.
Abstract. - Relations between Alpine detachment-bounded metamorphic domes, crustal-scale strike-slip fault zones and sedimentary basins in the Internal zones of the Betic cordillera are still matter of debate. Current tectonic interpretations of these basins vary from late-orogenic extensional structures to compressional ones associated with strike-slip motions along major still active faults. Structural investigations including new field mapping, meso-scale faults recognition, palaeostress analysis of brittle small-scale faults systems were performed in the sedimentary cover of the Almanzora corridor and the Huércal-Overa basins, located either in the hanging wall unit of the Filabres extensional shear zone or at the termination of the Alhama de Murcia sinistral fault zone. In parallel, a detailed study of the ductile and the ductile-brittle deformation was carried out in the footwall unit of the Filabres extensional shear zone, in the NevadoFílabride complex. Three main brittle events were recognised in the basin cover including two extensional events that occurred prior to a weak tectonic inversion of the basin during a third, still active event. The first one, $\mathrm{D} 1_{\mathrm{b}}$ is characterized by the development a first stress regime consistent with $\sim \mathrm{NW}$-SE extensional tectonics. Besides, the consistency between the latest ductile and the brittle kinematics for the Filabres extensional shear zone and the activity of meso-scale fault systems that primarily control the main SW-NE depocentres allow concluding to a top-to-the-NW continuum of strain during the final exhumation of the Nevado-Filábride complex. The resulting overall half-graben architecture of the basins is then related to the combination of the formation of the metamorphic domes that added a local control superimposed on the regional deformation. Indeed, after a consistent top-to-the-west shearing prevailing during most of the Nevado-Filábride exhumation, final exhumation stages were in turn, characterised by important kinematics changes with a subordinate top-to-the-NW sense of shear $\left(\mathrm{D} 1_{\mathrm{b}}\right)$. The onset of sedimentation in the basins occurred shortly after the crossing of the ductile-brittle transition in the underlying metamorphic domes at ca. 14 Ma into SW-NE fault-bounded troughs. Tectonic subsidence was then maintained during $\mathrm{D} 2_{\mathrm{b}}$ while extensional kinematics changed to $\mathrm{N}-\mathrm{S}$ or even locally to SSW-NNE. Extensional tectonics then lasted most of the Tortonian during the final tectonic denudation increments of the Sierra de los Filabres achieved at ca. 9-8 Ma. Intramontane basins are therefore genuinely extensional and clearly related to the latest exhumation stages of the Nevado-Filábride complex in the back-arc domain. Conversely, at ca. $8 \mathrm{Ma}$, basins started to record a $\sim \mathrm{N}-\mathrm{S}$ to NNW-SSE compressional stress regime (D $3_{\mathrm{b}}$ ) and ceased to be active depocentres while shortening within the Internal zones then recorded only the Iberia/Africa convergence. The weak inversion of the basins however resulted either in the reactivation of originally extensional faults such as the Alhama de Murcia fault or the basin individualisation and a progressive water exchange reduction with the Atlantic ocean and is thus proposed to be directly responsible for the Late Miocene salinity crises.
\end{abstract}

\section{Evolution ductile à cassante, tardi- à post-orogénique des Cordillères bétiques : apports d'une étude structurale du Nord-Est des zones internes}

Mots-clés. - Exhumation, Extension, Paléocontraintes, Tectonique en inversion, Crises de salinité.

Résumé. - Les relations entre les dômes métamorphiques alpins limités par des détachements, les zones de failles décrochantes crustales et les bassins sédimentaires sont toujours débattues dans les zones internes des Cordillères bétiques. Les interprétations tectoniques de ces basins varient depuis des structures tardi-orogéniques purement extensives à des structures compressives associées aux mouvements senestres le long de failles décrochantes majeures encore actives. Une étude structurale incluant un nouveau travail de cartographie, la reconnaissance des failles d'échelle intermédiaire, la détermination des paléocontraintes grâce à l'inversion de données de microfailles a été entreprise dans la couverture sédimentaire des bassins de Huércal-Overa et du corridor de l'Almanzora, localisés à la fois dans l'unité située au toit de la zone de cisaillement extensive des Filabres et à la terminaison de la zone de faille senestre d'Alhama de Murcia. En parallèle, une étude détaillée de la déformation ductile et ductile-fragile a été réalisée dans l'unité située au mur de la zone de cisaillement des Filabres dans le complexe Nevado-Filábride. Trois principaux événements cassants ont été reconnus dans la couverture sédimentaire dont deux épisodes extensifs suivis d'une inversion tectonique modérée du bassin durant un troisième épisode, toujours actif aujourd'hui. Le premier, $\mathrm{D} 1_{\mathrm{b}}$ est caractérisé par un premier régime de contrainte compatible avec une extension $\sim \mathrm{NW}$-SE. En outre, la cohérence entre les derniers incréments de la déforma-

1. Univ. d'Orléans, ISTO, UMR 7327, 45071 Orléans, France - romain.augier@univ-orleans.fr - Tel: (00 33) 238494011

2. CNRS/INSU, ISTO, UMR 7327, 45071 Orléans, France

3. BRGM, ISTO, UMR 7327, BP 36009, 45060 Orléans, France

4. UPMC, ISTEP, UMR 7193, 75252 Paris, France

5. Total S.A., 92078 Paris, La Défense cedex, France

6. Centre d'Hydrogéologie et de Géothermie, Université de Neuchâtel, Neuchâtel, Suisse

Manuscript received on February 28, 2012; accepted on August 7, 2012 
tion ductile et la déformation cassante sur la zone de cisaillement des Filabres, la cinématique des failles d'échelle intermédiaire qui contrôle les principaux dépocentres orientés SW-NE ont permis de conclure à un continuum de déformation NW-SE durant l'exhumation finale du complexe Nevado-Filábride. La géométrie de premier ordre en demi-graben est donc le résultat de processus tardi-orogéniques incluant l'extension $\sim \mathrm{E}-\mathrm{W}$ arrière-arc liée au retrait vers l'ouest du panneau plongeant et la formation des dômes métamorphiques ajoutant un contrôle plus local à la déformation régionale. En effet, après un cisaillement vers l'ouest généralisé durant la majeure partie de l'exhumation du complexe Nevado-Filábride, les stades tardifs de l'exhumation ont été caractérisés par un important changement de cinématique avec des sens de cisaillement locaux vers le NW $\left(\mathrm{D} 1_{\mathrm{b}}\right)$. Le début de la sédimentation semble avoir suivi de peu le passage de la transition ductile-fragile dans le dôme métamorphique sous-jacent vers 14 Ma au sein de fossés orientés SW-NE, limités par des failles normales majeures. La subsidence tectonique a ensuite été maintenue durant l'événement $\mathrm{D} 2_{\mathrm{b}}$ avec des directions d'extension d'avantage orientées N-S à SSW-NNE. La tectonique en extension a donc duré une grande partie du Tortonien alors que la dénudation tectonique de la Sierra de los Filabres s'est arrêtée vers 9-8 Ma. Les bassins intramontagneux sont donc véritablement extensifs et clairement reliés aux stades les plus tardifs de l'exhumation du complexe Nevado-Filabride. Réciproquement, vers $8 \mathrm{Ma}$, les bassins ont commencé a enregistrer un régime de contraintes en compression $\sim \mathrm{N}-\mathrm{S}$ à NW-SE $\left(\mathrm{D} 3_{\mathrm{b}}\right)$ et ont cessés d'être des dépocentres actifs alors que le raccourcissement dans les zones internes n'enregistraient plus que la convergence Ibérie/Afrique. L'inversion tectonique limitée des bassins a pourtant occasionné la réactivation des failles initialement extensives, comme la faille d'Alhama de Murcia et une individualisation forte des bassins ainsi que la diminution progressive des échanges en eau avec l'océan Atlantique et semble donc être directement responsable des crises de salinité de la fin du Miocène.

\section{INTRODUCTION}

The Betic-Rif orogen forms the westernmost part of the Alpine orogenic system and results from the closure of the Tethys ocean between Africa and the Iberian peninsula. Subduction and crustal thickening leading to the formation of high-pressure and low-temperature (HP/LT) metamorphic complexes were followed by a late-orogenic extension stage [Platt et al., 1998; Jolivet and Faccenna, 2000] in an overall convergent setting. Plate kinematic reconstructions indeed reveal a continuous convergence between Africa and Eurasia from Late Cretaceous times currently characterised by slow convergence rates of ca. $4 \mathrm{~mm} /$ year in a NW-SE direction [e.g. Dewey et al., 1989; De Mets et al., 1990; Rosenbaum et al., 2002; Serpelloni et al., 2007]. These boundary conditions add and interfere in complex ways with internal, body forces, stored during crustal thickening stages and subsequently released during crustal thinning. In the whole Mediterranean domain, late-orogenic evolution of large Alpine segments led to the formation of independent highly-arcuate double-vergent orogenic systems controlled by the behaviour of slabs in the upper mantle [i.e. Royden et al., 1993; Wortel and Spakman, 2000; Faccena et al., 2004; Spakman and Wortel, 2004].

At first sight, the Internal zones of the Betic cordillera are currently characterised by an alternation of $\sim \mathrm{E}-\mathrm{W}$ trending large-scale open basement antiforms (i.e. metamorphic domes) and associated narrow elongated structural basins (fig. 1). The internal structure of the metamorphic domes displays a stack of metamorphic complexes bounded by regional scale extensional shear zones reactivating initial major thrusts (fig.1) [i.e. Platt, 1986; Platt and Vissers, 1989; Gonzalez-Casado et al., 1995; Augier et al., 2005b]. Moreover, a major additional feature of the Internal zones is a prominent set of SW-NE major left-lateral fault, namely the Palomares, Carboneras and Alhama de Murcia fault zones regarded as the onland expression of a crustal shear zone that crosses the whole Alboran domain (fig. 1) [i.e. De Larouzière et al., 1988]. Such a peculiar geodynamic situation and the current apparent inconsistency of the largescale structures fostered a debate about the respective contributions of extensional and compressional regimes in the present-day finite geometry. In particular, the origin of sedimentary basins, referred to intramontane basins that developed within the Internal zones during Neogene times is still disputed. Basins are indeed diversely interpreted as resulting from late-orogenic extensional processes, strike-slip tectonics (e.g. pull-apart basins) or simply flexural synclines [Bousquet and Montenat, 1974; Bousquet et al., 1975; Montenat et al., 1977; Bousquet, 1979; Ott d'Estevou and Montenat, 1990; Mora, 1993; Vissers et al., 1995; Silva et al., 1997; Montenat and Ott d'Estevou, 1999; Poisson et al., 1999; Augier, 2004; Meijninger and Vissers, 2006; Pedrera et al., 2007, 2009, 2010, 2012]. In order to test these various interpretations, this study explores the tectonic record of the prominent $\sim \mathrm{E}-\mathrm{W}$-trending Huércal-Overa and Almanzora corridor basins, lying either in the hanging wall of a major extensional shear zone (e.g. FSZ; fig. 1) roofing the Sierra de los Filabres metamorphic dome and or located at the termination of the major, still active Alhama de Murcia strike-slip fault (AMF on fig. 1) as well as their relative basement. A detailed analysis of brittle deformation including new field mapping, meso-scale faults recognition, palaeostress analysis of small-scale fault systems was performed mostly in the sedimentary cover. Structural fabrics and kinematic indicators as well as their relations with published changing metamorphic P-T conditions and geochronological data were also studied in the Nevado-Filábride metamorphic complex. This study particularly addresses the link between crustal-scale, deep-seated processes such as the exhumation of the Alpine metamorphic rocks and their coeval sub-surface expression. The two Late Miocene salinity crises are also discussed as a possible consequence of the Late Miocene tectonic inversion of the extensional basins.

\section{GEOLOGICAL SETTING}

The Betic cordillera has been traditionally divided into an external fold-and-thrust belt referred to as the External Zones, and a mostly Alpine metamorphic hinterland called the Internal zones (fig. 1). Present-day architecture of the Internal zones can be geometrically described as "open 
domes and basins" type morphology with E-W trending metamorphic domes flanked by narrow Neogene sedimentary basins [e.g. Martínez-Martínez et al., 2004]. Metamorphic domes currently correspond to structural culminations [Vissers et al., 1995; Martínez-Martínez and Azañón, 1997] of three metamorphic complexes, from bottom to top the Nevado-Filábride, Alpujárride and Malaguide complexes, separated from each other by crustal-scale extensional shear zones [Platt, 1986; García-Dueñas et al., 1992; Lonergan and Platt, 1995; Platt et al., 2005; Augier et al., 2005c]. While the Malaguide complexe is usually devoid of alpine metamorphic imprint, the Alpujarride and the NevadoFilábride complexes both contain $\mathrm{HP}$ relics related to subduction and crustal thickening phases [e.g. Goffé et al., 1989; Gómez-Pugnaire and Fernández-Soler, 1987; Azañón and Crespo-Blanc, 2000; Puga et al., 2002; Augier et al., 2005a; 2005c]. The Alpujárride metamorphic complex is indeed characterized by the widespread occurrence of Fe-Mg-carpholite, kyanite, $\mathrm{Mg}$-rich chloritoid or aragonite [Goffé et al., 1989; Azañón and Goffé., 1997; Azañón et al., 1998] yielding locally peak-conditions of the order of 10-12 kbar for $450-500^{\circ} \mathrm{C}$ [Azañón and Crespo-Blanc, 2000]. The age of the HP-LT event is not well established with ages ranging from ca. 48 to $30 \mathrm{Ma}$ and thus still debated [Monié et al., 1991; Platt et al., 2005; Michard et al.,
2006]. The complex has been divided into five allochthonous units, defined upon differences in metamorphic record [Azañón et al., 1994] separated by ductile-brittle low-angle shear zones that acted as large-scale extensional shear zones during the exhumation of the complex [GarcíaDueñas et al., 1992; Crespo-Blanc et al., 1994]. The main step of the exhumation occurred through a fast $\sim \mathrm{N}-\mathrm{S}$ regional penetrative extensional event between 22 and $18 \mathrm{Ma}$ mainly accommodated by the Contraviesa low-angle fault system [Monié et al., 1994; Crespo-Blanc et al., 1994; Crespo-Blanc, 1995; Platt et al., 2005]. The NevadoFilábride (NF) metamorphic complex [Egeler and Simon, 1969] crops out within two tectonic windows in the core of the metamorphic domes (fig. 1). No consensus currently exists on the timing and the kinematics of the peak pressure event in the NF complex, which ranges from the Early Eocene (48 Ma [Monié et al., 1991]), Oligocene (30 Ma [Augier et al., 2005c]) to as late as the Middle Miocene (17 Ma [López Sánchez-Vizcaíno et al., 2001; De Jong, 2003; Platt et al., 2006]). Conversely, late exhumation stages are better constrained with the recognition of a set of top-to-the-W or SW major shear zones roofing and locally cutting down the NF complex (fig. 1), namely the Mecina shear zone and the Filabres shear zone (FSZ) that were active sequentially [Martínez-Martínez et al., 2002]. Timing

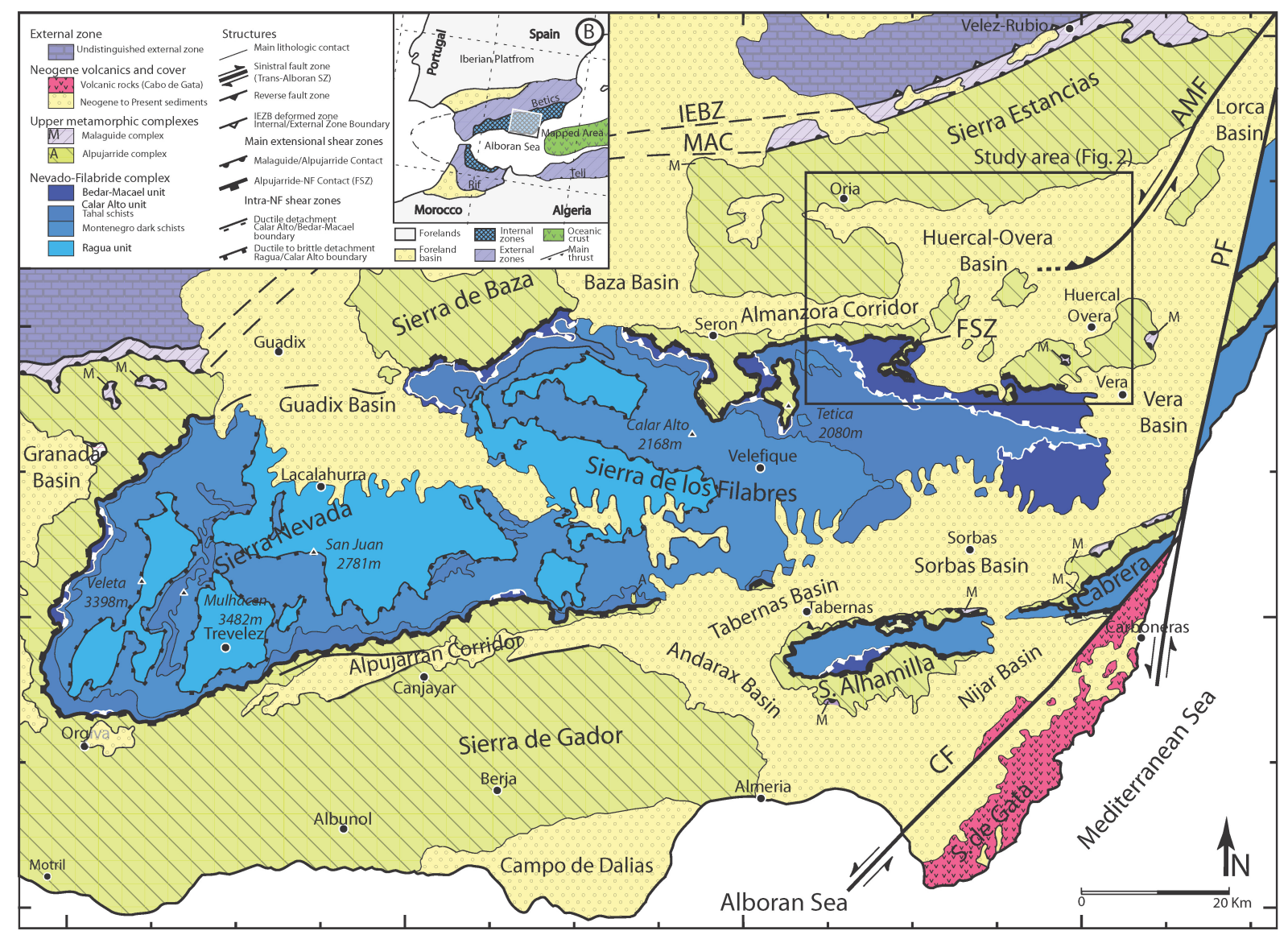

FIG. 1. - Tectonic maps and location of the studied area.

(a) Tectonic map of the southeastern part of the Internal zones of the Betic cordillera. Located are the main metamorphic domes of the Sierra de los Filabres/Nevada and the Sierra Alhamilla/Cabrera and the main sedimentary basins [modified after Augier et al., 2005b]. Also indicated are the main tectonic contacts such as the Filabres shear zone (FSZ) and the prominent sinistral fault zones pertaining to the Trans-Alboran transcurrent zone (CF: Carboneras fault, PF: Palomares fault et AMF: Alhama de Murcia fault) (b) Location of the Internal zones of the Betic Cordillera within the Gibraltar arc (inset). 
of the main exhumation stages under ductile conditions is constrained either by the clustering of cooling ages [De Jong and Bakker, 1991; Monié et al., 1991; Platt et al., 2005] or by in-situ dating on both greenschist facies assemblages and synkinematic mineral blastesis in deformed rocks between ca. 17 and 13 Ma [e.g. Augier et al., 2005c]. Final exhumation stages, constrained by fission-tracks (FT) and $\mathrm{U}-\mathrm{Th} / \mathrm{He}$ cooling ages took place from $11.9 \pm 0.9 \mathrm{Ma}$ (FT on zircons), $8.9 \pm 2.9 \mathrm{Ma}$ (FT on apatites), and $8.7 \pm 0.7 \mathrm{Ma}$ for recent $\mathrm{U}-\mathrm{Th} / \mathrm{He}$ analysis on apatites [Johnson et al., 1997; Vázquez et al., 2011]. As FT on apatites reveal that the Alpujárride complex reached the surface at ca. $18 \mathrm{Ma}$ [Johnson, 1995; Platt et al., 2005], the NF complex thus only represented a core complex with respect to the Alpujárrides between 18 to $9 \mathrm{Ma}$ that thus acted as the passive, pre-metamorphic FSZ hanging wall. It is also noteworthy that the last exhumation stages appear synchronous with the inception of sedimentation in the neighbouring basins characterised by the coarse grained continental deposits carrying the first NF detritus [Sanz de Galdeano and Vera, 1992; see also Meijninger, 2006 for a review]. However, extensional shear zones are not the only crustal-scale structures in the Betic cordillera. Indeed, the still active Palomares, Carboneras and Alhama de Murcia sinistral strike-slip fault zones also control and determine, at least a part of the neotectonic setting in eastern Betic cordillera (fig. 1 [e.g. Weijermars, 1987; Reicherter and Reiss, 2001; Booth-Rea et al., 2003]). These fault zones have been interpreted as parts of a wide crustal-scale shear zone (Trans-Alboran transcurrent zone, TATZ; fig. 1 [Leblanc and Olivier, 1984; De Larouzière et al., 1988]) crossing the Alboran sea and extending southwestward to Morocco. The NE-SW trending Alhama de Murcia fault [AMF; fig. 1; Bousquet and Montenat, 1974] extending over $\sim 100 \mathrm{~km}$, from Murcia to the north as far as the Huércal-Overa basin to the south, forms the northern segment of this transcurrent zone (fig. 1) and shows dominantly sinistral kinematics or more local reverse kinematics along the WSW-ENE trending segments [Martínez-Díaz, 2002; Meijninger and Vissers, 2006]. The most recent fault activity currently associated with moderate seismicity [Stich et al., 2003] is mostly inferred from geomorphological studies and deformation of the Quaternary cover [e.g. Masana et al., 2005].

\section{The intramontane basins: infilling, structure and models of formation}

Two sedimentary infill pulses are recognised in most of the basins of the Internal zones [e.g. Ott d'Estevou and Montenat, 1990; Sanz de Galdeano and Vera, 1992; Montenat and Ott d'Estevou, 1999] which seems to be related with major, regional-scale extensional events [Sanz de Galdeano and Vera, 1992; Crespo-Blanc et al., 1994; Crespo-Blanc, 1995; Martínez-Martínez et al., 2002] presumably also responsible for the exhumation of the Alpujárride and the Nevado-Filábride metamorphic complexes. The first generation of basins, Burdigalian-Langhian in age is particularly recognised in the western parts of the Internal zones [i.e. Serrano et al., 2006, 2007]. To the east, only few outcrops are preserved [Serrano, 1990]. Lying unconformably on the Malaguide and the Alpujárride complex, these basins often appear conspicuously associated with $\sim \mathrm{E}-\mathrm{W}$ trending, generally top-to-the-N extensional structures (i.e. the Contraviesa extensional system [Crespo-Blanc, 1995]).

A second generation of basins then formed from the late Serravallian onward [Sanz de Galdeano and Vera, 1992; Vissers et al., 1995] and are generally referred to as intramontane basins [e.g. Meijninger 2006; Pedrera et al., 2010]. At the scale of the Betic orogenic system, stratigraphy of these intramontane basins is comparable from one basin to another sharing the same turning-points during their evolution [e.g. Sanz de Galdeano and Vera, 1992]. However, particular events such as the Mediterranean-wide Messinian salinity crisis (MSC), is so far only recognized in the Tabernas, Sorbas, Níjar, Vera or Lorca basins [e.g. Ott d'Estevou and Montenat, 1990; Bache et al., 2011 and references therein]. To a lesser extent than the MSC, the Tortonian salinity crisis (TSC), also occurred in the northeastern part of the Internal zones and is well documented in the Fortuna basin [Krijgsman et al., 2000; Tent-Manclús et al., 2008]. While the tectonic cause producing the TSC are well accepted [Tent-Manclús et al., 2008], processes leading to the MSC are disputed and the respective roles of global eustacy, horizontal shortening or regional-scale uplift related to deep-seated processes are debated [Adams et al., 1977; Hodell et al., 1986; Weijermars, 1988; Krijgsman et al., 1999a; Duggen et al., 2003; Jolivet et al., 2006; Luján et al., 2011].

These mostly $\sim \mathrm{E}-\mathrm{W}$ trending elongated sedimentary basins are encased between the main metamorphic domes while some other basins are rather aligned along the Trans-Alboran transcurrent zone and appear linked, at least geographically, to normal faults, sinistral faults and even subordinates thrust faults (fig. 1). Initial discovery of the first-order sinistral shear zone invited earlier workers to interpret the intramontane basins as a mosaic of faultbounded basins including wrench furrows, pull-aparts, compressional and extensional relay basins [Bousquet and Montenat, 1974; Bousquet et al., 1975; Montenat et al., 1977; Bousquet, 1979; Ott d'Estevou and Montenat, 1990; Sanz de Galdeano and Vera, 1992; Silva et al., 1997; Montenat and Ott d'Estevou, 1999; Poisson et al., 1999; Soler et al., 2003 and Masana et al., 2004] formed as a direct consequence of the Eurasia/ Africa convergence.

On the other hand, the recognition of low-angle extensional shear zones able to exhume deep-seated metamorphic rocks sometimes equilibrated in eclogitic conditions rather suggests a late-orogenic collapse [Platt and Vissers, 1989; García-Dueñas et al., 1992; Jabaloy et al., 1993; Vissers et al., 1995; Martínez-Martínez et al., 2002, 2004; Augier et al., 2005b; Agard et al., 2011] active as recently as the Late-Miocene [Monié et al., 1994; Johnson et al., 1997; Augier et al., 2005c; Platt et al., 2005; Vázquez et al., 2011]. In parallel, extensional structures, with variable kinematics have also been described in the onshore basins [e.g. Mora, 1993; Vissers et al., 1995; MartínezMartínez and Azañón, 1997; Amores et al., 2001, 2002; Augier, 2004; Ruano et al., 2004; Meijninger and Vissers, 2006] or offshore in the Alboran basin [e.g. Comas et al., 1992, 1999; Mauffret et al., 1992; Watts et al., 1993]. There is thus a debate opposing two contrasting interpretations of the basins and these two opposed views still coexist nowadays [e.g. Pedrera et al., 2007, 2010]. 


\section{The Huércal-Overa and the Almanzora corridor basins}

The Huércal-Overa basin is an ENE-WSW-trending rectangular basin in direct structural and stratigraphical connection with the $\sim \mathrm{E}-\mathrm{W}$-trending Almanzora corridor basin. These basins that probably share a common evolution are thus grouped hereafter into a single basin (figs. 1 and 2). The Miocene sedimentary infill consistently dips gently toward the south and the whole stratigraphic succession can be studied along N-S incised valleys [Augier, 2004]. The structure of the basin is markedly asymmetric with a gentle onlap of the basin on the Alpujárride basement to the north contrasting with a fault-bounded southern contact and thus defining an overall half-graben geometry [e.g. Mora, 1993; Vissers et al., 1995]. There, younger deposits are usually faulted against a narrow fringe of Alpujárrides and minor klippes of Malaguides separated from the NF complex by the regional-scale extensional FSZ (fig. 2) [Martínez-Martínez et al., 2002].

Stratigraphic succession of the basin has been thoroughly studied [Briend, 1981; Briend et al., 1990; Ott d'Estevou and Montenat, 1990; Mora, 1993; Poisson et al.,
1999; Augier, 2004; Meijninger and Vissers, 2006; Pedrera et al., 2010; see Meijninger, 2006 for a detailed review]. Despite minor, disrupted and poorly represented sediments attributed to the Serravallian [e.g. Briend et al., 1990; Guerra-Merchán and Serrano, 1993], the basinfill is mainly dominated by a thick Upper Miocene series reaching locally $\sim 1500$ m [i.e. Mora, 1993; Augier, 2004] confirmed by recent gravity surveys (fig. 2b) [Pedrera et al., 2009, 2010]. The Huércal-Overa basin is characterised by two main SW-NE asymmetric troughs reaching up to 1000-1500 m of thickness aligned respectively along the Sierra de Almagro and along a series of basement highs within the basin (fig. 2b) [Pedrera et al., 2010]. The western prolongation of this trough turns to a more $\sim \mathrm{W}$-E orientation that forms the Almanzora corridor basin [Pedrera et al., 2007].

Through a major erosional unconformity, the base of the series is marked by a ca. $800 \mathrm{~m}$-thick red continental breccia and conglomerate formation attributed to the uppermost Serravallian-Lower Tortonian boundary [Briend et al., 1990; Ott d'Estevou and Montenat, 1990]. Preferred flow directions (fig. 2), consistent with a dominant supply from

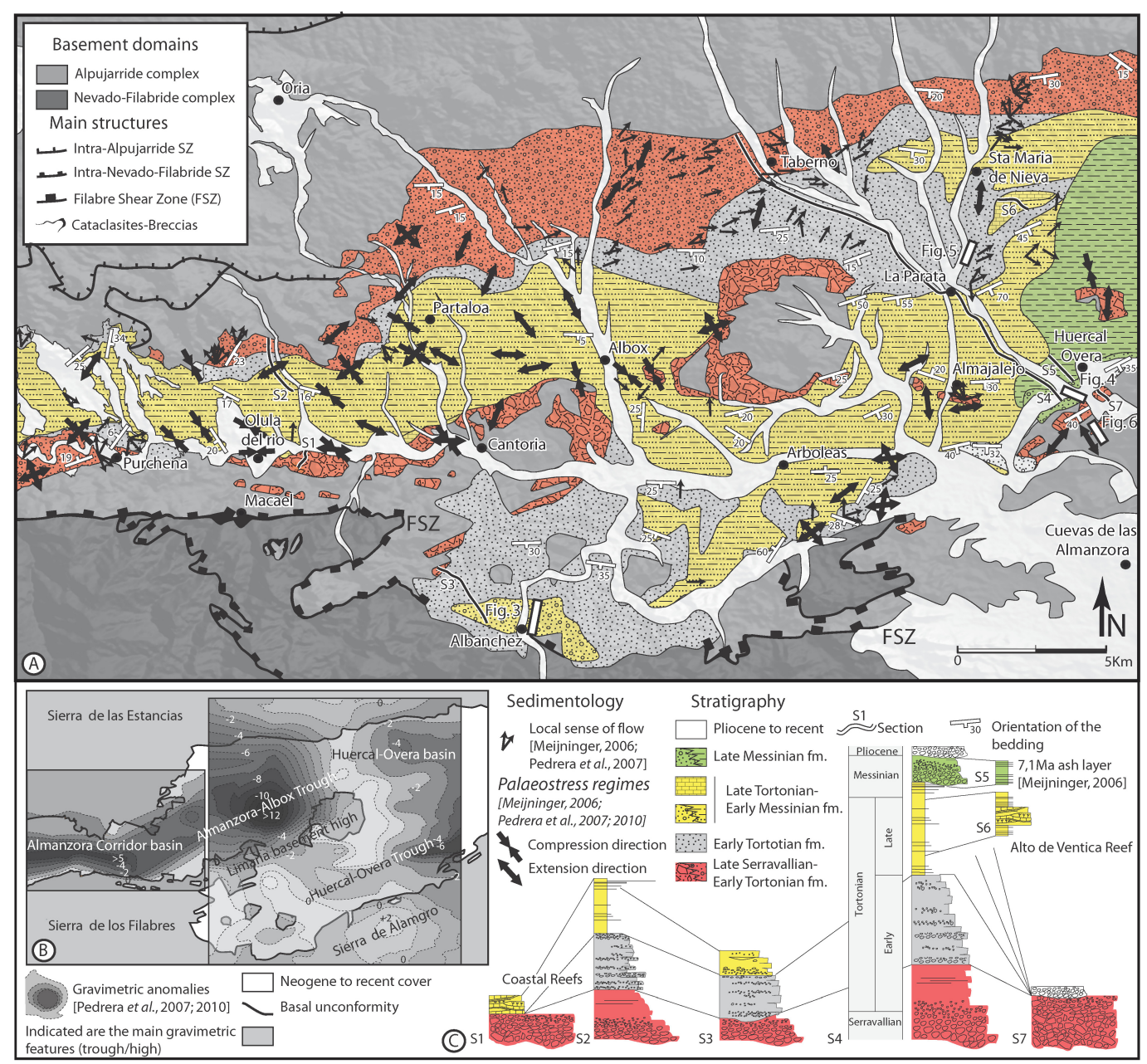

FIG. 2. - Study area synthesis map centered on the Huércal-Overa and Almanzora corridor basins. (a) Compilation of kinematic data and palaeostress results are from [Meijninger, 2006; Pedrera et al., 2007, 2010]. Compilation of local sense of flow is from Meijninger, [2006] and Pedrera et al. [2007]. Traces of major shear zones in the basement areas are from Martínez-Martínez et al. [ 2002]; Augier et al. [2005b]; Platzman and Platt [2004]. (b) Results (residual gravity anomalies) of gravity surveys performed within the Almanzora corridor and the Huércal-Overa basins [Pedrera et al., 2009, 2010]. Minimum values of ca. $-12 \mathrm{mGal}$ residual gravity anomalies correspond to a ca. 1000-1500 m-thick sedimentary infill [Pedrera et al., 2010]. (c) Lithostratigraphic succession and correlations across the Huércal-Overa and Almanzora corridor basins inspired after [Guerra-Merchán and Serrano, 1993]. Section S4 is presented in details in Augier [2004]. 
the Nevado-Filábride are generally toward the E despite local variations probably related with the internal geometry of the fans [e.g. Meijninger, 2006; Pedrera et al., 2007]. A general consensus exists on the lateral equivalence between this coarse clastic formation and at least the upper part of the basal red breccia encountered along the faults bounding the basin margins and fringing basement highs within the basin [Mora, 1993; Augier, 2004]. These continental deposits pass gradually upward and partly laterally into a ca. 300-500 m-thick grey shallow marine formation dated to the Early Tortonian [Briend, 1981; Guerra-Merchán and Serrano, 1993; Guerra-Merchán et al., 2001; Meijninger, 2006]. This formation, including conglomerates and sandstones interlayered with siltstones is characterised by a general grain-size fining upward and assigned to a near-shore deltaic environment; a possible distal equivalent for the underlying continental alluvial fan types. Lying in conformable contact to the north of the basin, this formation acquires a clear transgressive character to the south where it unconformably overlies the Alpujárride basement rocks (fig. 2a and 2c). Through a limited regressive sequence [Mora, 1993; Augier, 2004; Meijninger, 2006], the Early Tortonian is overlain by a $\sim 500-800 \mathrm{~m}$-thick transgressive formation of dominant yellow silty-marls dated from the Late Tortonian-Early Messinian [Guerra-Merchán and Serrano; 1993; Martín-Pérez, 1997; Meijninger, 2006]. In more details, these open-marine sediments are encountered in the centre of the basin and they pass laterally to reef complexes to the north (e.g. Alto de Ventica reefs [Mora, 1993]) or shallow marine conglomerates to the south. It is also noteworthy that the active depocentre of the basin migrated again to the South where thick series of conglomerates lie unconformably or in faulted contact with the Alpujárride or even directly the Nevado-Filábride basement (i.e. Albanchez area; fig. 2a and 2c). Late Messinian only crops out in the southeastern part of the basin through a local yet marked unconformity. There, thick coarse-grained conglomerates laterally interfinger into dated Late Messinian marine marls [Briend, 1981; Meijninger, 2006]. The eastern part of the basin is extensively covered by thick series of Pliocene to Quaternary deposits that makes the connection with the Pulpi basin through a large, monotonous plain (fig. 2).

Despite numerous studies performed in these basins having a significant component of structural geology [e.g. Briend, 1981; Briend et al., 1990; Ott d'Estevou and Montenat, 1990; Mora, 1993; Barragán, 1997; Poisson et al., 1999; Meijninger, 2006], only a few palaeostress analyses were conducted [Meijninger and Vissers, 2006; Pedrera et al., 2007, 2010]. Results, compiled on figure 2 are internally consistent and show two preferred orientations of extension oriented $\sim$ SSW-NNE and NW-SE and a $\sim$ NW-SE to $\mathrm{N}-\mathrm{S}$-trending compression. Interpretations of these data are however contrasted and feed the above mentioned models.

\section{METHODOLOGY}

A detailed structural analysis of the basinfill and the adjacent basement areas has been performed over a ca. $40 \mathrm{x}$ $30 \mathrm{~km}$ area centred on the village of Albox (fig. 2). Structural study of the basin cover, characterised by brittle deformation consisted in palaeotress tensors reconstructions complemented by detailed mapping of the meso-scale fault systems. Thanks to the recognition of numerous stratigraphic time-markers, the succession of stress regimes is reasonably well constrained in time. This study is complemented by the analysis of the underlying NF basement that recorded, in addition to the above-mentioned brittle deformation earlier deformation stages mostly acquired in ductile conditions.

\section{Structural analysis of the sedimentary cover}

A brittle micro-tectonic analysis allowed to reconstruct changing palaeostress fields that have successively affected both the Huércal-Overa and the Almanzora corridor basins and to infer how and when the meso-scale fault systems were formed and to recognise their successive episode of activity. Thanks to good outcrop conditions, these major faults were identified using detailed field survey and highresolution mapping on aerial pictures and satellite images.

\section{Description of brittle structures and the data set collection}

The whole study area presents a pervasive network of small-scale to meso-scale fault systems. Running over more than $250 \mathrm{~km}$, the Filabres shear zone (FSZ) is the only large-scale structure that was active under both ductile and subsequent brittle conditions and thus played a major role during the exhumation of the Nevado-Filábride complex [e.g. Martínez-Martínez et al., 2002; Augier et al., 2005b]. The Alhama de Murcia fault [e.g. Meijninger and Vissers, 2006] is also a major brittle structure characterised by a present-day sinistral kinematics. However, in the study area, this fault rapidly dies out into the northern part of the Huércal-Overa basin along the $\sim \mathrm{E}-\mathrm{W}$ Albox reverse fault [García-Meléndes et al., 2003].

The dataset for this study is made of heterogeneous small-scale fault populations measured on 52 sites within the Huércal-Overa and the Almanzora corridor basin sedimentary cover where all the outcropping stratigraphical units of the basin were visited. As it experienced a complex polyphased tectono-metamorphic history basement rocks have not been studied in detail for the brittle analysis, except when relations with sedimentary rocks and/or older (ductile) deformation were unambiguous. Inversion of fault-slip data was carried out using a representative number of measured striated fault planes (983 in total), joints and tension gashes (297) and bedding attitude (for each site) with a set of 15-25 faults routinely collected at each site. Sense of slip, inferred from kinematic indicators such as striae and grooves, Riedel subordinate planes, tensile cracks and more routinely from slickensides (i.e. calcite steps; see review in Doblas [1998]) were determined. Displacement on faults ranges typically between few $\mathrm{cm}$ and few meters (micro-scale faults) while displacement over meso-scale faults generally exceeds several hundreds of meters.

\section{Dating the successive palaeostress states}

Changing stress fields leading to the successive formations of new fault sets and/or the possible reactivation of inherited faults results in the accumulation of brittle structures as a heterogeneous fault set. For each site, this set has been splitted into homogeneous, cogenetic fault populations 
distinguished considering the "Palaeostress-stratigraphy" concept of Kleinspehn [Kleinspehn et al. 1989] based either on stratigraphic considerations or structural observations [e.g. Vandycke and Bergerat, 2001]). Therefore, fault sets described in the "results" section are then presented as separated homogeneous sets of faults.

\section{Syn-sedimentary and stratigraphic (s.l.) age constraints for the deformation}

Syn-sedimentary deformation is a common feature in the Huércal-Overa basin. Normal faulting that occurred during sedimentation or the early diagenesis stages within the basin has already been documented in many previous studies toward which the reader is referred for more details [Briend, 1981; Briend et al., 1990; Ott d'Estevou and Montenat, 1990; Mora, 1993; Augier, 2004; Meijninger and Vissers, 2006; Pedrera et al., 2007, 2010, 2012]. Only new descriptions of syn-sedimentary and stratigraphic age constraints are now presented in details.

Syn-sedimentary extension has already been described within the Late Serravallian-Early Tortonian continental formation [Meijninger, 2006]. The most typical features include the development of coeval top-to-the-NNW shallow dipping normal faults and WSW-ENE sedimentary dykes [Mora, 1993] or the formation of $\sim \mathrm{E}-\mathrm{W}$ extensional roll-over anticline (e.g. Almajalero area; fig. 2; Meijninger [2006]).

In the Early Tortonian shallow marine formation, geometry of the normal faults seems clearly related to the strong lithologic (i.e. rheologic) layering of the sequence. While normal faults generally develop as $50-70^{\circ}$-dipping roughly planar surfaces in the sandstone or conglomerate layers, they conversely display a gentle to flat dips in the siltstone or claystone layers. These two types of faults, both oriented $\sim \mathrm{W}-\mathrm{E}$ to NW-SE interact and often form flat-ramp-flat systems or sets of steep normal faults that bend down on a layer-parallel gently-dipping master normal faults [Mora, 1993; Augier, 2004; Meijninger, 2006; Pedrera et al., 2012]. Arguments including bed omission and rapid lateral changes of both the sedimentary facies and the thickness of the layers in the vicinity of the faults strongly argue for an extensional deformation that occurred during sedimentation [see e.g. Briend, 1981 for the first observations]. An emblematic example of syn-sedimentary roll over development in the hanging-wall of a very gently NW-SE trending fault plane is given along the Santopétar cross-section [Briend, 1981; Briend et al., 1990; Mora, 1993; Meijninger, 2006]. The consistent $\sim \mathrm{W}$-E to NW-SE orientation of the fault trace direction and the associated slickenside lineation carried by fault planes, irrespective of the delta palaeoslope [Ott d'Estevou and Montenat, 1990; Meijninger, 2006; Pedrera et al., 2007] clearly discard a pure gravitational origin as already described in deltaic context [e.g. Maloney et al., 2010; Pedrera et al., 2012].

The Albanchez area also displays syn-sedimentary normal faulting deformation in the lower part of the Late Tortonian-Early Messinian formation (see fig. 2 for location). Along a $5 \mathrm{~km}$ long $\sim \mathrm{NNE}-\mathrm{SSW}$ section between the South of Cantoria and Albanchez, the series display a consistent SW-dip. Figure 3 displays a field-landscape interpretation accompanied with bedding measurements for the southern part of the section, north of Albanchez. There, bedding attitude displays a large-scale syn-sedimentary roll-over anticline developed above a $\sim \mathrm{N} 120$ trending meso-scale normal fault (fig. 3a and 3d). Partly eroded and devoid of clear morphological scarps, this normal fault however separates the Late Tortonian sediments from the Alpujárride basement with a probable plurihectometric offset (fig. 3). At the scale of the outcrop, massive coarse-

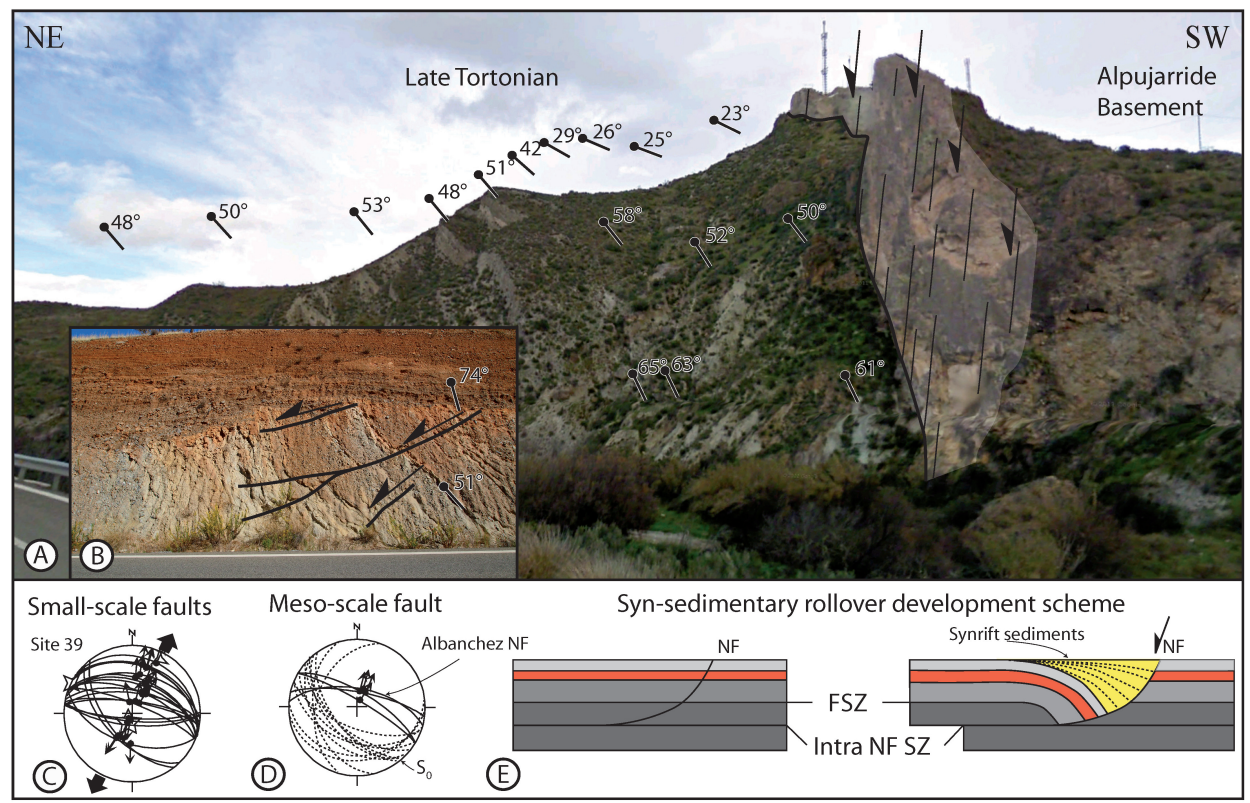

FIG. 3. - Field examples of syn-sedimentary dating criteria.

(a) Landscape picture of a large-scale syn-sedimentary roll-over developed during the Late-Tortonian. Note the growth-strata displaying a clear thickening toward the main normal fault. (location: N 37 $17^{\prime} 41,05^{\prime \prime}$; W $02^{\circ} 10^{\prime} 51,31$ "). (b) Late Tortonian conglomerate beds involved in the roll-over horizontal-axis rotation; small-scale pre-tilting normal faults control the bed thickness distribution. (c) Site 39 diagram showing a wide range of dip for the normal faults. Pre-tilting low-angle syn-sedimentary fault sets coexist with syn- and post-tilting normal fault sets. (d) Projection of the bedding attitude of the late Tortonian growth-strata and the fault planes associated with the Albanchez normal fault. (e) Syn-sedimentary roll-over development scheme. 
grained conglomerates and sandstones bars interbedded with silty-marls layers are affected by a small-scale yet penetrative multiple generations of normal faults (fig. $3 \mathrm{~b}$ and 3c). The first generations, showing clear syn-sedimentary features, present a current gentle to flat dip cutting the bedding with angles of the order of $45-50^{\circ}$ and controlling the bed thickness distribution (fig. 3b). During progressive tilting, these faults were passively rotated and displaced by new normal faults. Last normal fault generation shows conjugate sets with a dominance of NE-dipping fault planes affecting the steeply SW-dipping bedding, thus indicating that normal faults were formed continuously prior, during and partly after tilting (fig. 3c).

The structural development and the sedimentation of the Huércal-Overa and the Almanzora corridor basins appear controlled at all-scale by normal faulting from Late Serravallian-Early Tortonian onward. Orientation of faults (and the associated kinematics) however evolves from SW-NE to WSW-ENE in the basal formation to more W-E to NW-SE for the Early Tortonian shallow marine formation.

The upper bound of the age of extensional structures can be crudely bracketed to the south of the Huércal-Overa basin. There, Late Tortonian sediments, affected by intense normal faulting are unconformably overlain by a thick series of yellow conglomerates attributed to the late Messinian (fig. 4). Extensional tectonics is thus sealed by the Messinian as first proposed by Meijninger [2006]. Conversely, the Messinian is often affected by significant tilting (fig. 4) and the post-Messinian cover appears itself faulted by either reverse and/or wrench faults. The uppermost Tortonian-Messinian period therefore appears as the main turning-point in the evolution of the basin corresponding to the inception of the tectonic inversion of the basins.

\section{Discrimination of successive tectonic events by structural criteria}

Most of the visited sites display evidence of polyphase faulting and are then characterised by the inhomogeneous character of the data sets. In addition to stratigraphic criteria presented and discussed above, relative chronology based on structural (s.l.) criteria may yield an accurate discrimination of successive tectonic events. Two field examples illustrate the routine analyse carried out when a visiting structural site used for palaeostress reconstructions (see fig. 2 for location).

An example of geometrical relationships between faulting and folding is given on figure 5. There, two sets of faults affect the uppermost part of the Early Tortonian shallow marine formation where the bedding, characterised by the alternation of sandstones and more silty-layers presents a SW-directed moderate dip. The dominant set of faults, made of both normal and reverse faults displays flat to gently NE- and SW-dipping fault planes sharing a consistent top-to-the-NE kinematics (figs. 5a and 5d). A close-up view of a representative kinematic indicator is given in figure 5b. A subordinate set also presents both normal and reverse kinematics on sub-vertical faults. Besides, it is also noteworthy that the sandstone layers are conspicuously affected by a single set of layer-orthogonal joints and tension gashes. In their present geometry, none of the computed principal stress axes is vertical and the two other principal stress axes are contained within the bedding in the calculated palaeostress solution thus suggesting pre-folding

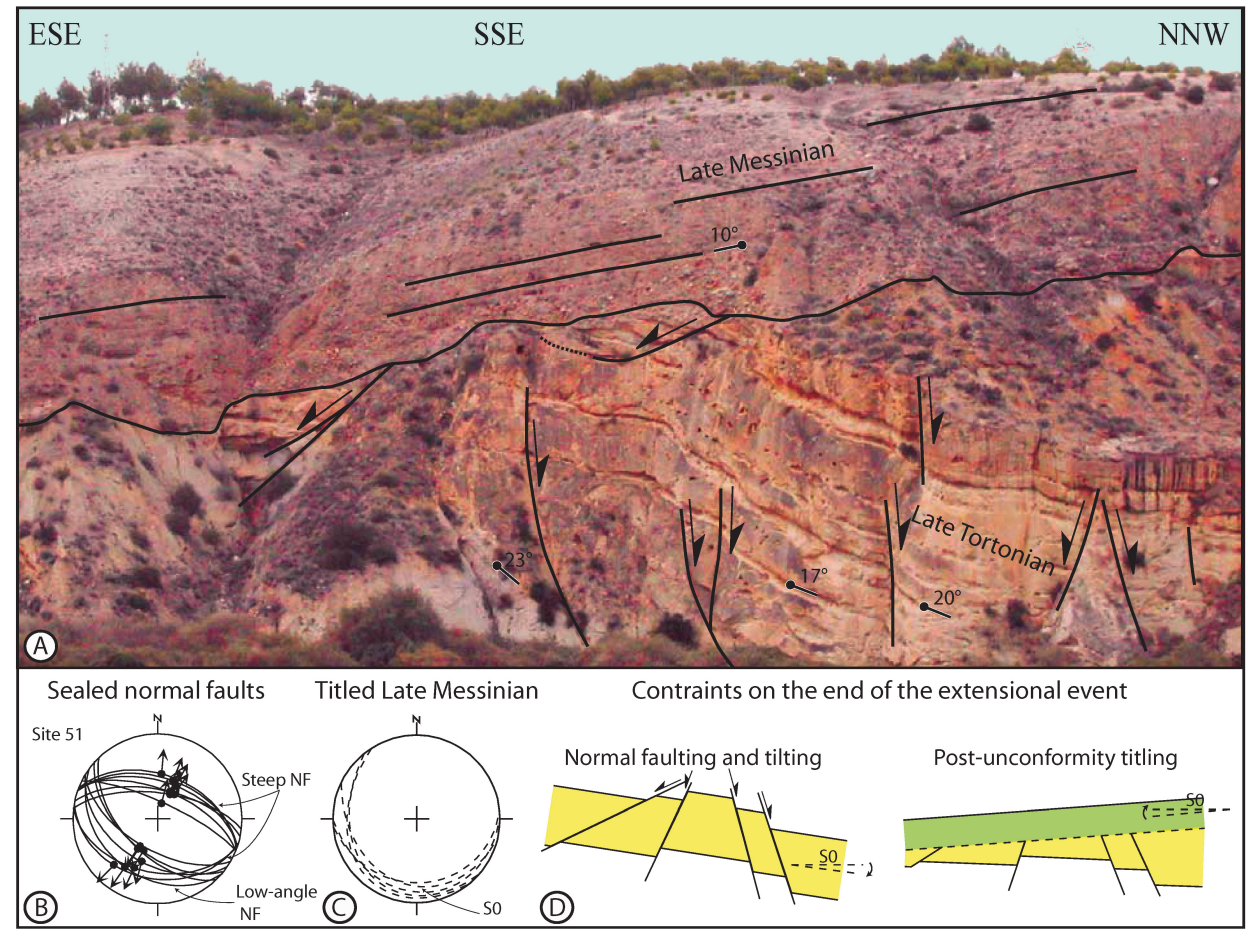

FIG. 4. - Stratigraphic criteria for a brittle events relative chronology.

(a) Late-Tortonian heavily affected by extensional deformation and tilted below the Late Messinian unconformity (location: N $37^{\circ} 22^{\prime} 53,63^{\prime \prime}$; W $\left.01^{\circ} 56^{\prime} 57,88^{\prime \prime}\right)$. It is noteworthy that the unconformity is itself subsequently titled. (b) and (c) Diagrams showing the NW-SE normal fault population sealed below the Messinian unconformity (site 51) and the current attitude of the Late Messinian bedding. (e) A two-stepped sketch depicting the probable evolution of the outcrop. 
faults (fig. 5d). These principal stress axes become horizontal after back-tilting about a horizontal axis and the resulting back-tilted stress state is then in agreement with the Andersonian model (fig. 5e [Anderson, 1942]). This assumption is confirmed $\sim 150 \mathrm{~m}$ further the SW where the bedding displays a gentler attitude (i.e. $5-10^{\circ}$ toward the $\mathrm{SW}$, fig. 8c) while joints and tension-gashes are now subvertical and all the faults appear as a single conjugate normal fault set thus preserved in their initial geometry. Occurrence of $\sim \mathrm{E}-\mathrm{W}$ clastic dykes (i.e. a syn-sedimentary argument), rotated in the folded area are here subvertical, orthogonal to the bedding (fig. 5c).

Most of the studied sites display evidence of polyphase faulting and therefore include reactivated fault planes carrying different sets of slickensides; one of the most reliable criteria of relative chronology between two tectonic events. A field example is given on figure 6. There, the outcrop is characterised by a steep faulted contact between the Late Serravallian-Early Tortonian continental formation and the Alpujárride basement rocks striking NE-SW (i.e. parallel to the Huércal-Overa fault [Mora, 1993]; fig. 2). Detailed analysis of the fault plane revealed at least three slickenside lineations, associated with tension cracks and accurate kinematic indicators (fig. $6 \mathrm{~b}$ and $6 \mathrm{c}$ ). The first two motions are dominantly vertical and down-dip, in particular for the first

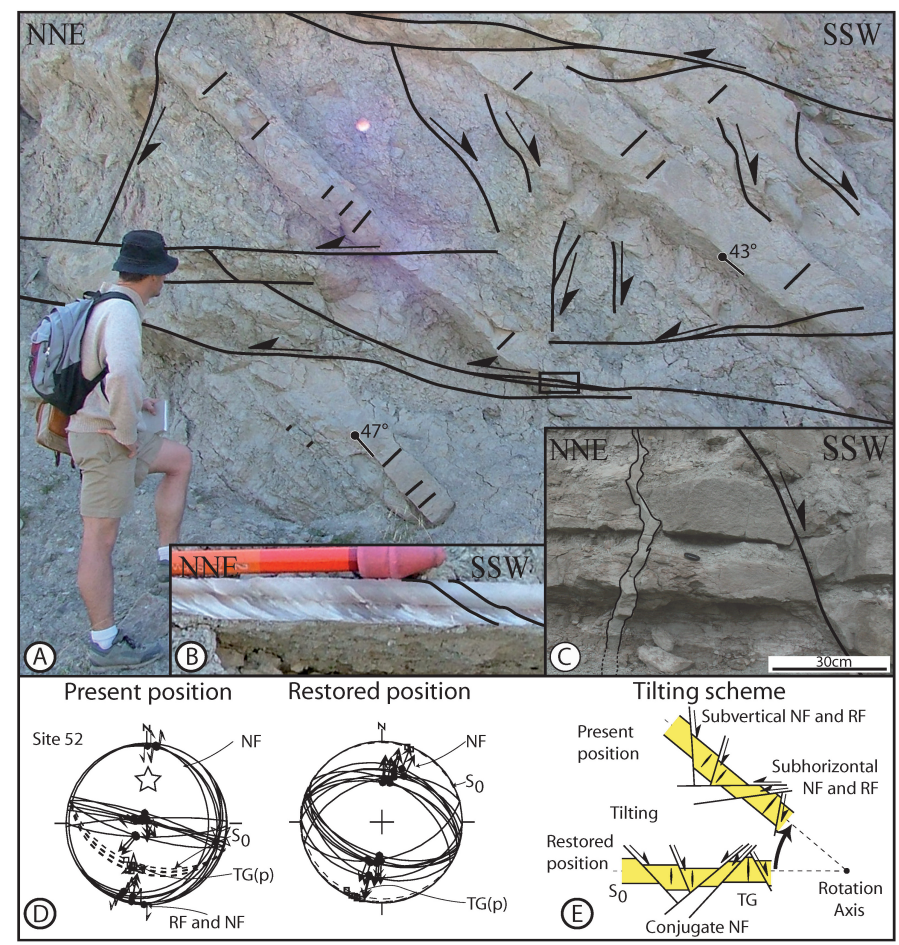

FIG. 5.- Relations between faulting and folding.

(a) Outcrop picture of Early Tortonian shallow marine formation heavily affected by pre-tilting extensional deformation. Note the penetrative pre-tilting conjugate normal faults that currently occur as both flat and subvertical sets of both normal and reverses faults and the array of bedding-orthogonal tension gashes. Inset (b) is a close-up view of sheared gypsum fibbers indicating a top-to-the-NNE motion over a gently SSW-dipping reverse fault (a pre-tilting normal fault). Inset (c) is an outcrop picture (150 m north of the main outcrop) showing that deformation occurred shortly after deposition as evidenced by clastic dyke injection. (d) Diagrams showing site 52 before and after back-tilting rotation. NF referred to normal faults, RF to reverse faults, S0 to bedding and TG to tension gashes; $\mathrm{p}$ is for "pole". (e) Schemes represent pre-tilting and post-tilting (current) fault set geometry with respects to the bedding and the tension gashes. one (i.e. S1 on fig. 6a). Steeply-dipping Riedel faults and tension cracks developed at right angle of the slickenside lineation clearly show that these first two motions are related to normal faulting. Such kinematics thus complies with the two extensional directions recognised in the previous section. The last motion over the fault plane then presents sub-horizontal slickenside lineations with a clear left-lateral movement (fig. $6 \mathrm{c}$ and $6 \mathrm{~d}$ ) attested by a reactivated Riedel plane (fig. 6c). Similar, yet smaller-scale fault plane reactivation evidences are shown in figure $6 \mathrm{~d}$.

Based on these criteria and fault cross-cutting relations however rarely observed in the field, the total fault population has been grouped into three main sets. Precise orientation of both fault sets and the resulting inversion of fault-slip data for stress are presented in chapter Structure and kinematics of the Nevado-Filabride complex.

\section{Palaeostress analysis}

A variety of methods have been proposed to estimate palaeostress states from field measurements of fault striations on fault planes for natural fault systems [e.g., Carey and Brunier, 1974; Angelier, 1984, 1990, 1994; Lisle, 1987, 1988; Hardcastle and Hills, 1991; Fry, 1992, 1999; Žalohar and Vrabec, 2007].

Palaeostress orientation patterns were evaluated by the computer-aided inversion method for fault-slip data, which is described in detail by Angelier [1984, 1990 and 1994]. The reduced palaeostress tensor consists in the identification of the orientation of the three principal stress axes $\left(\sigma_{1}\right.$, $\sigma_{2}, \sigma_{3}$, the maximum, intermediate and minimum stress axes respectively), and the ratio $\Phi=\left[\left(\sigma_{2}-\sigma_{3}\right) /\left(\sigma_{1}-\sigma_{3}\right)\right]$ reflecting the relative magnitude of principal stress axes (axial ratio of stress ellipsoid). Determination of the palaeostress axes have been supplemented and strengthened by the analysis of other accompanying brittle structures such as joints, and tension gashes (open or filled by calcite, gypsum and iron oxy-hydroxydes; see Hancock [1985] or Doblas [1998]). The study was carried out in weakly strained areas in order to avoid stress perturbation within and at the direct vicinity of important fault zones. The fault population used in this study is composed of microfaults populations embracing structures ranging from centimetres to decametres faults associated cogenetic micro-faults, which are observable on a single and continuous exposure. Kinematics of meso-scale faults as well as large-scale faults were also investigated but were not included in the palaeostress reconstruction.

\section{Structural analysis of the ductile deformation in the Nevado-Filábride complex}

Basement domains mostly consist of metamorphic rocks belonging to the two lower metamorphic complexes recognised in the Betic-Rif orogenic system, the Nevado-Filábride and the Alpujárride complexes. Related to older tectonometamorphic events, the structural evolution of the Malaguide and the Alpujárride complexes has not been investigated.

The rocks of the Nevado-Filábride complex are often highly deformed in ductile conditions. Most of the deformation concentrated along the Filabres shear zone [GarcíaDueñas et al., 1992; Jabaloy et al., 1993; MartínezMartínez et al., 2002; Augier, 2004; Augier et al., 2005b; 


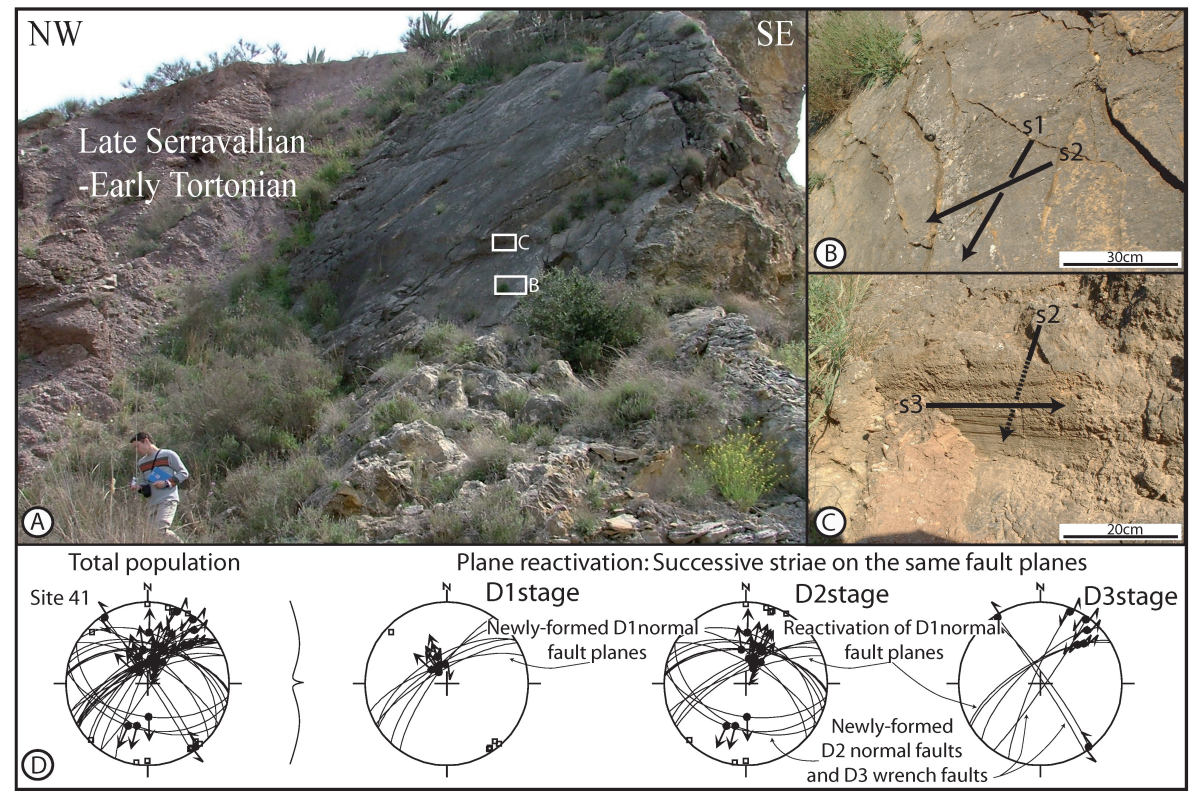

FIG. 6. - Tectonic reactivation of fault planes.

a) Outcrop picture of Late Seravallian-Early Tortonian continental formation faulted against the Alpujárride basement rocks (location: N $37^{\circ} 22^{\prime} 27,91^{\prime \prime}$; W 01 56'16,54"). This basin-bounding meso-scale fault plane carries three successive slickenside lineations. Insets (b) and (c) are close-up views of parts of the fault plane where either two lineations or the relative chronologic criteria are preserved (see location over the plane on (a). (c) Diagrams showing the site 41 total fault population. Separation into homogeneous fault sets reveals that part of the initial normal (D1 $1_{b}$ ) faults is reactivated during two subsequent events $\left(\mathrm{D} 2 \mathrm{~b}\right.$ and $\mathrm{D} 3_{\mathrm{b}}$ ). NF referred to normal faults, RF to reverse faults, S0 to bedding and TG to tension gashes; $\mathrm{p}$ is for "pole".

Agard et al., 2011], leaving large volumes where older tectonometamorphic events are preserved, at least partly [Augier et al., 2005b]. The complete structural evolution of the Nevado-Filábride complex is beyond the focus of this study, the reader unfamiliar with the geology and the evolution of the complex is referred to pioneer works [Galindo-Zaldívar et al., 1989; García-Dueñas et al., 1992; Jabaloy et al., 1993] as well as recent syntheses [MartínezMartínez et al., 2002; Augier et al. 2005b]. Conversely, this study focussed on the most prominent ductile features that mostly correspond to structures developed during, and mostly at the end of the exhumation of the NevadoFilábride complex well recorded near the FSZ (D2 $2_{d} D 3_{d}$; [Augier et al., 2005b]. For each station, the main stretching direction(s) and the sense of shear are reported on the map in figure 7.

\section{STRUCTURE AND KINEMATICS OF THE NEVADO-FILABRÍDE COMPLEX}

The Nevado-Filábride complex is characterised by a strong and regionally developed planar-linear fabric (i.e. S2/L2 with respects to D $2_{\mathrm{d}}$ event [Augier et al. 2005b]). This foliation that shapes the overall dome-geometry of the NF complex intensifies toward the FSZ from rather low-strain domains where older fabrics (e.g. $\mathrm{D} 1_{\mathrm{d}}$ ) are still observable. In the whole Sierra de los Filabres, the upper part of the NF complex, the main foliation carries a strong stretching lineation trending roughly NNE-SSW to ENE-WSW [Jabaloy et al., 1993; Augier et al., 2005b]. In the field, this lineation is associated with lower amphibolite facies retrograde mineral assemblages like biotite, chloritoid and locally staurolite. Deformation appears overwhelmingly dominated by an intense subvertical flattening associated with an $\sim \mathrm{E}-\mathrm{W}$ stretching (fig. 7).
Evidence for clear non-coaxial flow is however conspicuously observed into the upper $\sim 500-700 \mathrm{~m}$ of the NF complex below the FSZ. There, the deformation is characterised by an overall, regional-scale top-to-the-W or more locally top-to-the-SW sense of shear [e.g. Jabaloy et al., 1993] marked in the field by the pervasive development of a late extensional crenulation cleavage [Platt, 1979, 1984]. This deformation stage (D3 ${ }_{\mathrm{d}}$ event [Augier et al. 2005b]), while in direct continuity and in partial structural accordance should not be mixed with $\mathrm{D} 2{ }_{\mathrm{d}}$. This cleavage, locally highly penetrative, is restricted to the vicinity of major shear zones, in particular along the FSZ and mainly observed in the Permian-Triassic light-schists as well as in the uppermost part of the Paleozoïc black-schists where overlying lithostratigraphic units are tectonically thinned (e.g., fig. 1). In the field, a few sites display two stretching lineations, L2 and L3 (fig. 7). The second one, L3, associated with the late extensional crenulation cleavage is characterised with the crystallisation of large amounts of greenschists facies minerals such as elongated chlorite, phengite and globular, syn-kinematic albite that clearly postdates the S2/L2 paragenesis. At the scale of the study area, lineation trajectories draw curved patterns evolving from WNW-ESE toward the south (i.e. the dome axis) to NW-SE or even NNW-SSE, to the north, at the vicinity of the FSZ while, conversely, the L2 lineation remains consistently oriented $\sim \mathrm{E}-\mathrm{W}$ (fig. 7 ). ${ }^{40} \mathrm{Ar} /{ }^{39} \mathrm{Ar}$ time constraints on the latest mineral recrystallisations along the FSZ yielded ca. 17-13 Ma ages either in the Sierra de los Filabres or in the Sierra Alhamilla [Augier et al., 2005c; see also Platt et al., 2005].

Displacement over the FSZ under brittle conditions is attested by a sometime thick $(5-150 \mathrm{~m})$ zone of cataclasites, fault rocks, mylonitic gypsum and carbonate matrix breccias 
mainly derived from the underlying greenschists mylonite zone (i.e., $\mathrm{D} 3_{\mathrm{d}}$ zone) and the Alpujárrides hanging wall. Late large-scale corrugations over the FSZ and slickensiderich breccias along low-angle normal faults permit to precise the kinematics of the brittle stage (named $\mathrm{D} 1_{\mathrm{b}}$ event; fig. 7 [Augier et al. 2005b]). Despite a limited data set, the last ductile deformation (D3 $3_{\mathrm{d}}$ ) shows a good consistency with respect to the subsequent brittle deformation. Timing of brittle deformation is constrained by the whole spectrum of near-surface thermochronometers from 12 to $8 \mathrm{Ma}$ [Johnson, 1993; Johnson et al., 1997; Vázquez et al., 2011].
Relationships between these final exhumation stages of the NF complex are discussed in the lights of the palaeostress analysis of the FSZ hanging wall unit carrying the sedimentary basins.

\section{RESULTS OF THE BASIN COVER PALAEOSTRESS ANALYSIS}

Three main brittle (D1b, D2b, D3b) tectonic events characterised in the field have been recognised in the studied sites. The



FIG. 7. - Results of both the structural analysis of the basement areas and the analysis of the D1 brittle event. Traces of D1 meso-scale faults are mapped and their local kinematics is indicated. Sites that recorded the D1 event are located with a synthetic presentation of the stress regime. (b) Detailed results of the palaeostress analysis. (c) Schematic geological cross-sections tacking into account field observations, structural measurement and gravity results from Pedrera et al. [2009, 2010]. 

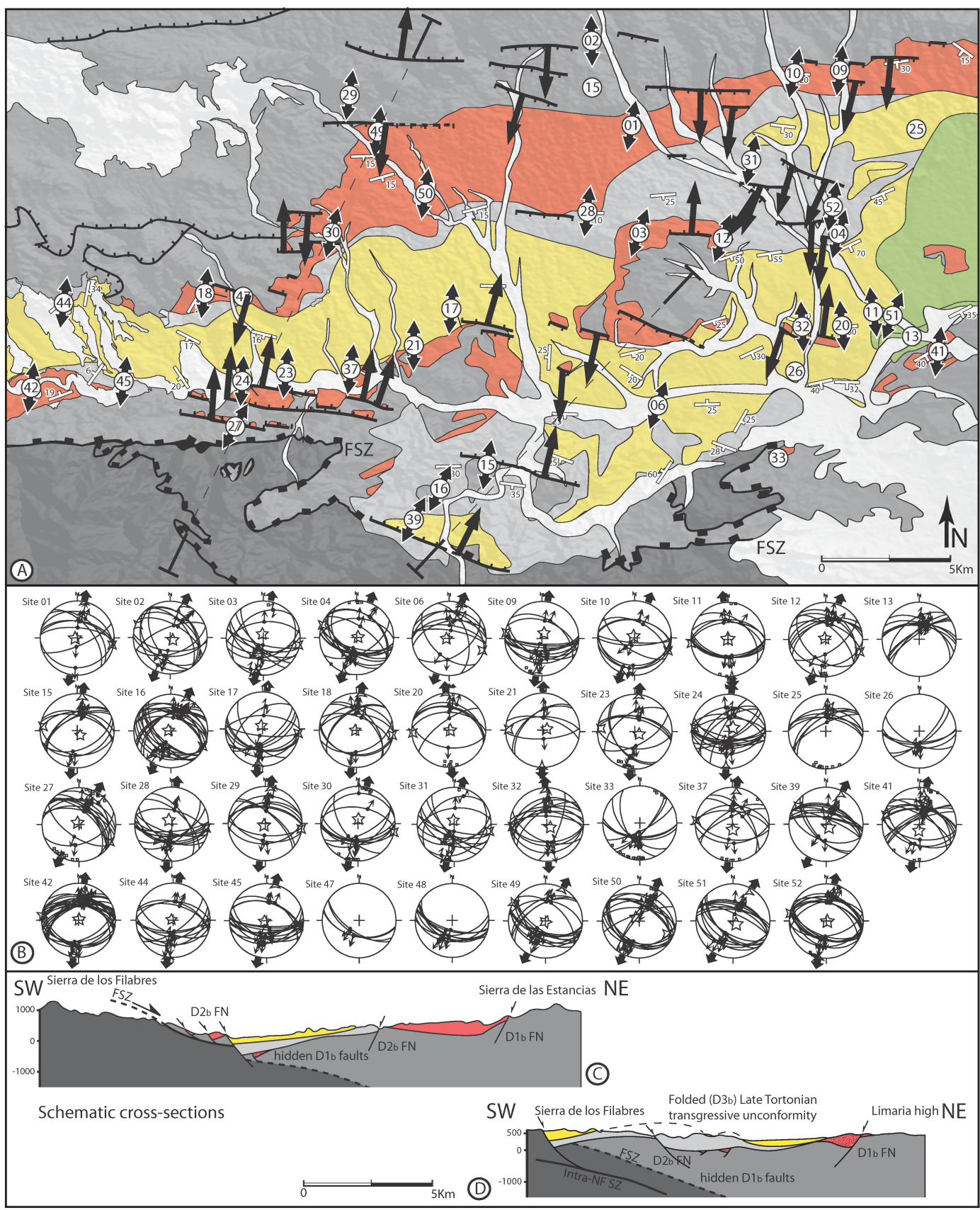

FIG. 8. - Results of the analysis of the D2 brittle event. Legend is given on figure 7. (b) Detailed results of the palaeostress analysis. (c) Schematic geological cross-sections tacking into account field observations, structural measurement and gravity results from Pedrera et al. [2009, 2010].

complete brittle analysis allows establishing the succession of theses tectonic events as follows. Results are compiled in table I and are graphically shown in the maps of figures 7,8 and 9 corresponding to the combination of the existing geologic 1/50,000 sheets [Garciá-Monzón et al., 1975; Garciá-Monzón and Kampschuur, 1975; Simón et al., 1978; Voersmans et al., 1980], previous studies [Briend et al., 1981; 1990; Mora, 1993; Augier, 2004; Meijninger and Vissers, 2006; Barragán, 1997; Pedrera et al., 2007, 2010], new field mapping and lineament analysis of aerial pictures and satellite images.

\section{Palaeostress tensor group D1 $1_{b}$ (NW-SE to NNW-ESE extension)}

The oldest brittle tectonic event, partly syn-sedimentary recorded in the sedimentary cover area is mostly recorded by the Late Serravallian-Early Tortonian continental formation [Mora, 1993] and throughout the adjacent basement rocks. Some initial normal faults were often subsequently tilted and now occur with various dips and are sometimes currently present as reverse faults. At small-scale, both low-angle and steep SW-NE trending normal faults seem to coexist depending on the local behaviour of the sediments (fig. 7 , 
sites $03,13,35,42$ ) while basement rocks are cut by steep planar SSW-ENE to SW-NE normal faults (sites 34). The associated stress tensor corresponds to a subhorizontal extension $\left(\sigma_{3}\right)$ mainly NW-SE directed with a subvertical maximum compression direction $\left(\sigma_{1}\right)$. On few sites, WNWESE to NW-SE trending faults seem to predate the NW-SE to NNW-SSE faults (fig. 7, sites $07,13,22,38,43,45$ ).

New field mapping highlighted meso-scale fault systems that affect exclusively the Late Serravallian-Early Tortonian continental formation and the Alpujárride basement along which it is generally faulted. Their identification in the field is limited, particularly to the south as they are unconformably overlain by younger formations (fig. 7). Their cartographic traces are thus partly inferred from gravimetric data (fig. 2). Associated net motions that appear large are rarely constrained in the field and can be again crudely bracketed to several hundred of meters to one kilometre, using gravity data [Pedrera et al., 2009, 2010]. Major faults, such as the Huércal-Overa, Cantoria or Olula del Rio-Albox faults (fig. 7) share a common NW dip with a relative uplift of basement rocks currently outcropping as series of basement highs. Subordinate SE-dipping antithetic faults also occur NW of Albanchez or NW of Taberno and intrabasinal faults are consequently sealed below a thick sedimentary cover. Landscape analysis and detailed field work embracing both Nevado-Filábride and Alpujárride basement rocks and the sedimentary cover of the Almanzora corridor seem to indicate that, at least a part of the meso-scale fault listrically bends down on the FSZ as viewed from the local diverging patterns of the bedding. In addition, it is noteworthy that palaeostress tensors for this event are consistent with the latest motions over the FSZ under brittle conditions. Two extension-parallel geological cross-sections are given on figure 7 . Inspired and based on both field observations and structural measurements, they largely benefited from gravity data [Pedrera et al., 2009, 2010].

\section{Palaeostress tensor group D2 ${ }_{b}$ (N-S to NE-SW extension)}

The second brittle tectonic event is characterised by a set of abundant N085-N $130^{\circ}$ E-trending normal faults (fig 8). This brittle event is recorded in all formations including most of the Late Tortonian-Early Messinian formation. A spectacular extensional syn-sedimentary deformation is observed in the Early Tortonian shallow marine formation as shown by bed omission, thickness changes of either side of faults as well as clastic dykes. The strong sedimentary rheological layering of this formation leads to flat-ramp-flat fault systems and sets of steep normal faults that bend down on a layer-parallel gently-dipping normal faults (fig. 8, sites 3, $16,19)$. In the underlying formations and in the basement, $\sim$ W-E and SW-NE normal faults are rather steep and planar. Newly formed $\mathrm{D} 2 \mathrm{~b}_{\mathrm{b}}$ normal faults are often accompanied by reactivated inherited $D 1_{b}$ faults (fig. 8 , sites $13,15,16,41$, 42) with an oblique motion (fig. 6). Beside, $\sim \mathrm{E}-\mathrm{W}$ to ESE-WNW-trending shear surfaces in the Alpujárride basement, which were formed under ductile conditions during early to middle Miocene times [Platt et al., 2005] are also sometimes reactivated (fig. 8, sites 2, 15, 29). However, an unambiguous separation is only possible when a

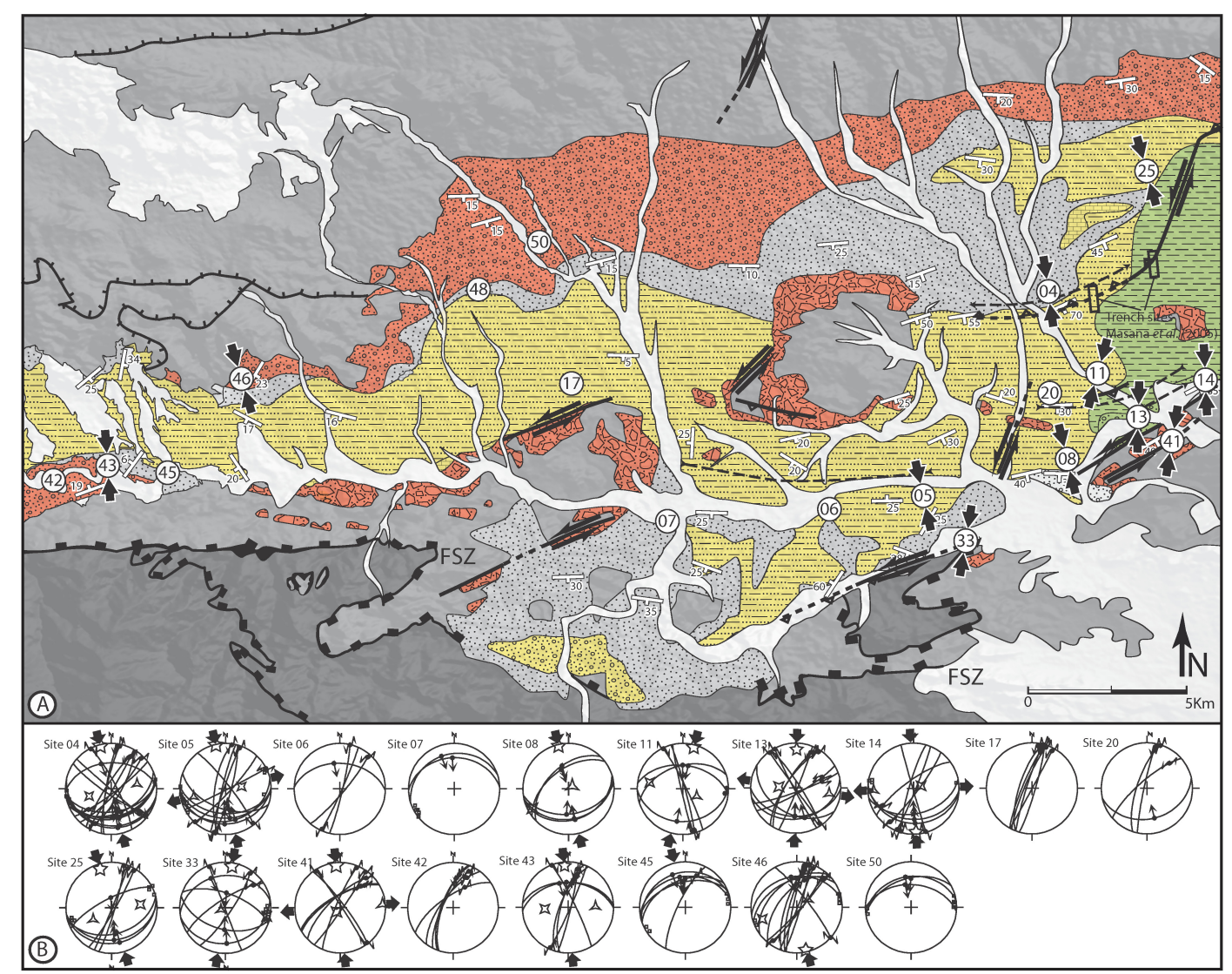

FIG. 9. - Results of the analysis of the D3 brittle event. Legend is given on figure 7. (b) Detailed results of the palaeostress analysis. 
sedimentary cover is present. This group of stress tensors is characterised by a subhorizontal extension $\left(\sigma_{3}\right)$, mainly $\mathrm{N}-\mathrm{S}$ to NNE-SSW and a subordinate NE-SW direction. The maximum compression direction $\left(\sigma_{1}\right)$ is subvertical. While this event may have started before, this stress state appears synchronous with the deposition of both the Early

TABLE I. - Detailed results of the palaeostress analysis. Indicated are, after a brief description of the site (stratigraphy, lithology and bedding/foliation attitude), the composition of the data-set and the results of the palaeostress tensor determination. RUP is a quality estimator. E and C indicate extensional, compressional regimes, respectively; direction is those of $\sigma 1$ for $\mathrm{C}$ regimes, and $\sigma 3$ for $\mathrm{E}$ regimes.

\begin{tabular}{|c|c|c|c|c|c|c|c|c|c|c|c|c|}
\hline General information & & & & & Data & base & & Calcu & ated res & & & \\
\hline $\mathrm{N}^{\circ}$ Station & Stratigraphic age & Dominant lithology & So/M & ittitude & $\mathrm{Nt}$ & $\mathrm{N}$ & Joints & $\mathrm{s}$ & 1 & S2 & & $\mathrm{S} 3$ \\
\hline & & & Dir. & Plung. & & & & Dir. & Plung. & Dir. & Plung. & Dir. \\
\hline 1 Cortijo de Fatiguas & E. Tor. & sandstones/conglomerates & 204 & 15 & 9 & 8 & & 263 & 86 & 101 & 4 & 11 \\
\hline 2 Lardea & E. Tor. & conglomerates/sandstones & 160 & 17 & 12 & 12 & & 133 & 82 & 292 & 7 & 23 \\
\hline 3 Loma Alta & L. Ser-E. Tor. & sandstones/conglomerates & 154 & 21 & 18 & 12 & 4 & 322 & 80 & 61 & 2 & 152 \\
\hline 3 & & & & & & 9 & 5 & 86 & 86 & 290 & 4 & 200 \\
\hline $4 \overline{\text { Las Zorreras }}$ & L. Ser-E. Tor. & sandstones/marls & 198 & 60 & 39 & 17 & 7 & 104 & 87 & 287 & 3 & 204 \\
\hline 4 & & & & & & 18 & 6 & 341 & 1 & 252 & 39 & 69 \\
\hline 5 Zurgena & L. Mes. & marls & 156 & 4 & 18 & 12 & 14 & 348 & 2 & 82 & 61 & 256 \\
\hline 6 Arboleas & L. Mes. & sandstones/marls & 342 & 1 & 15 & 9 & & 265 & 84 & 110 & 5 & 19 \\
\hline 6 & & & & & & 4 & & & & & & \\
\hline 7 Alto de la Yesera & L. Ser-E. Tor. & sandstones & 12 & 8 & 19 & 16 & & 32 & 84 & 243 & 5 & 153 \\
\hline 7 & & & & & & 2 & 6 & & & & & \\
\hline 8 La Sierrecica & L. Ser-E. Tor. & marls & 154 & 1 & 37 & 29 & 16 & 2 & 83 & 240 & 3 & 150 \\
\hline 8 & & & & & & 5 & & 347 & 4 & 77 & 5 & 221 \\
\hline 9 Las Minas & E. Tor. & conglomerates/sandstones & 194 & 7 & 20 & 13 & 3 & 22 & 77 & 280 & 3 & 189 \\
\hline 10 La Hoya & E. Tor. & conglomerates/sandstones & 182 & 12 & 12 & 10 & 4 & 278 & 87 & 104 & 3 & 14 \\
\hline 11 Cotijo del Cosario & L. Tor-E. Mes & marls & 54 & 9 & 17 & 9 & 5 & 355 & 89 & 264 & 0 & 174 \\
\hline 11 & & & & & & 6 & & 15 & 7 & 281 & 27 & 117 \\
\hline 12 Los Nofres & L. Tor-E. Mes & sandstones/conglomerates & 12 & 34 & 11 & 11 & 7 & 324 & 87 & 110 & 2 & 200 \\
\hline 13 La Cuesta Alta & L. Ser-E. Tor. & sandstones & 4 & 11 & 34 & 6 & 12 & & & & & \\
\hline 13 & & & & & & 14 & & & & & & \\
\hline 13 & & & & & & 11 & & 1 & 16 & 243 & 59 & 99 \\
\hline 14 Cortijo del Manchego & L. Mes. & sandstones & 6 & 1 & 9 & 8 & 6 & 177 & 4 & 70 & 76 & 268 \\
\hline 15 Cerro del Prior & Alp. basement & micaschists & 320 & 5 & 17 & 7 & & & & & & \\
\hline 15 & & & & & & 10 & & 144 & 82 & 282 & 8 & 12 \\
\hline 16 Cortijo Capellana & E. Tor. & conglomerates/sandstones & 12 & 8 & 36 & 32 & & 283 & 85 & 116 & 5 & 26 \\
\hline 17 Cortijo del Pozo & L. Ser-E. Tor. & sandstones/conglomerates & 3 & 24 & 23 & 5 & 12 & & & & & \\
\hline 17 & & & & & & 11 & & 343 & 82 & 97 & 3 & 187 \\
\hline 17 & & & & & & 6 & & & & & & \\
\hline 18 Cortijo el Porra & E. Tor. & conglomerates/sandstones & 8 & 18 & 11 & 10 & & 267 & 88 & 98 & 2 & 8 \\
\hline 19 Alto de jata & L. Ser-E. Tor. & sandstones/conglomerates & 321 & 6 & 18 & 12 & & 239 & 82 & 62 & 9 & 153 \\
\hline 20 NE-Almajalejo & L. Tor-E. Mes & marls & 8 & 2 & 16 & 7 & 8 & 99 & 87 & 265 & 3 & 355 \\
\hline 20 & & & & & & 4 & & & & & & \\
\hline 21 Torreon & L. Ser-E. Tor. & conglomerates/sandstones & 120 & 5 & 32 & 23 & 15 & 174 & 87 & 41 & 2 & 311 \\
\hline 21 & & & & & & 5 & & 74 & 80 & 271 & 9 & 181 \\
\hline $22 \overline{\text { Aljambra }}$ & L. Ser-E. Tor. & conglomerates/sandstones & 140 & 26 & 23 & 18 & & 146 & 76 & 40 & 4 & 309 \\
\hline 23 Las Entrenas & E. Tor. & sandstones/conglomerates & 196 & 17 & 9 & 8 & 11 & 119 & 79 & 276 & 10 & 6 \\
\hline 24 Olula del rio & E. Tor. & sandstones/conglomerates & 205 & 10 & 27 & 25 & & 52 & 78 & 276 & 9 & 184 \\
\hline 25 Cerro Tallante & L. Tor-E. Mes & marls/carbonates & 157 & 15 & 14 & 6 & 8 & & & & & \\
\hline 25 & & & & & & 7 & 9 & 344 & 13 & 83 & 36 & 237 \\
\hline 26 Los Carasoles & L. Tor-E. Mes & sandstones/marls & 120 & 3 & 6 & 6 & & & & & & \\
\hline 27 Cerro Sacristia & E. Tor. & sandstones/conglomerates & 185 & 17 & 16 & 12 & 16 & 324 & 85 & 119 & 5 & 209 \\
\hline 28 Los marcelinos & E. Tor. & sandstones & 212 & 15 & 15 & 14 & & 325 & 79 & 96 & 7 & 187 \\
\hline 29 Los Lozanos & Alp. basement & micaschists & 202 & 5 & 18 & 15 & & 214 & 86 & 99 & 2 & 8 \\
\hline$3 0 \longdiv { \text { La Cueva } }$ & Alp. basement & micaschists & 216 & 14 & 28 & 15 & 7 & 126 & 72 & 239 & 7 & 321 \\
\hline 30 & & & & & & 10 & 15 & 8 & 80 & 103 & 1 & 194 \\
\hline 31 Santopetar & E. Tor. & sandstones & 213 & 4 & 11 & 11 & 4 & 348 & 81 & 101 & 4 & 192 \\
\hline 32 Los Bonillos & L. Tor-E. Mes & marls/siltstones & 256 & 2 & 17 & 16 & & 129 & 80 & 266 & 7 & 357 \\
\hline $33 \overline{\text { Agua Arriba }}$ & L. Ser-E. Tor. & conglomerates/sandstones & 132 & 10 & 19 & 4 & & & & & & \\
\hline 33 & & & & & & 8 & 18 & & & & & \\
\hline 33 & & & & & & 7 & 9 & 9 & 9 & 100 & 4 & 214 \\
\hline $34 \overline{\text { Los Bancalicos }}$ & Alp. basement & micaschists & 172 & 35 & 7 & 7 & 7 & & & & & \\
\hline 35 Las Pilillas & L. Ser-E. Tor. & conglomerates & 120 & 9 & 11 & 10 & & 156 & 82 & 253 & 1 & 343 \\
\hline 36 El Canico & L. Ser-E. Tor. & conglomerates & 177 & 7 & 8 & 6 & & 308 & 79 & 57 & 4 & 148 \\
\hline 37 Las Mateas & L. Ser-E. Tor. & conglomerates & 144 & 13 & 14 & 5 & & & & & & \\
\hline 37 & & & & & & 8 & 7 & 175 & 78 & 276 & 2 & 7 \\
\hline 38 Los Cabecicos & L. Ser-E. Tor. & conglomerates & 12 & 4 & 17 & 15 & & 304 & 87 & 207 & 0 & 117 \\
\hline 39 San Roque & L. Tor-E. Mes & marls/carbonates & 204 & 17 & 19 & 18 & & 203 & 79 & 297 & 1 & 27 \\
\hline 40 Alto de las Canales & L. Ser-E. Tor. & conglomerates & 34 & 45 & 7 & 7 & & & & & & \\
\hline 41 Cortijo de Rodrigo & L. Ser-E. Tor. & conglomerates & 334 & 13 & 32 & 6 & 5 & & & & & \\
\hline 41 & & & & & & 15 & 8 & 185 & 76 & 281 & 1 & 30 \\
\hline 41 & & & & & & 7 & & 355 & 7 & 221 & 80 & 85 \\
\hline 42 Armuna de Almanzora & L. Ser-E. Tor. & conglomerates & 153 & 13 & 53 & 15 & & 51 & 86 & 242 & 2 & 335 \\
\hline 42 & & & & & & 26 & & 12 & 87 & 277 & 2 & 188 \\
\hline 42 & & & & & & 5 & & & & & & \\
\hline 43 W-Purchena & L. Ser-E. Tor. & conglomerates & 85 & 26 & 24 & 16 & 1 & 322 & 87 & 235 & 1 & 149 \\
\hline 43 & & & & & & 7 & & 353 & 9 & 228 & 44 & 87 \\
\hline 44 SE-Somotin & L. Ser-E. Tor. & conglomerates & 4 & 10 & 19 & 5 & & & & & & \\
\hline 44 & & & & & & 14 & & 281 & 87 & 97 & 12 & 194 \\
\hline $45 \bar{E}$ E-Purchena & L. Ser-E. Tor. & conglomerates/sandstones & 4 & 10 & 38 & 17 & 8 & 66 & 86 & 246 & 3 & 336 \\
\hline 45 & & & & & & 15 & & 281 & 87 & 104 & 12 & 13 \\
\hline 45 & & & & & & 5 & 5 & & & & & \\
\hline $46 \overline{\text { Agua Amarga }}$ & L. Ser-E. Tor. & conglomerates/sandstones & 200 & 16 & 15 & 2 & 1 & & & & & \\
\hline 46 & & & & & & 12 & 7 & 171 & 4 & 242 & 27 & 69 \\
\hline $47 \mathrm{Al}$ Merendero & E. Tor. & conglomerates & 175 & 14 & 9 & 4 & & & & & & \\
\hline 47 & & & & & & 4 & 4 & & & & & \\
\hline $48 \overline{\mathrm{N}-\mathrm{P} \text { artaloa }}$ & E. Tor. & conglomerates/sandstones & 185 & 13 & 9 & 9 & & & & & & \\
\hline $49 \overline{\text { El Penon Bajo }}$ & L. Ser-E. Tor. & conglomerates & 182 & 10 & 22 & 12 & 3 & 129 & 80 & 235 & 7 & 316 \\
\hline 49 & & & & & & 9 & & 128 & 86 & 304 & 3 & 29 \\
\hline 50 Llano del Espino & L. Ser-E. Tor. & conglomerates/sandstones & 156 & 20 & 29 & 6 & & & & & & \\
\hline 50 & & & & & & 18 & 5 & 297 & 78 & 124 & 17 & 207 \\
\hline 50 & & & & & & 3 & 6 & & & & & \\
\hline 51 SE Railway & E. Tor. & sandstones/marls & 334 & 23 & 15 & 14 & & 117 & 85 & 298 & 7 & 32 \\
\hline 52 Cortijo de Rodrigo & L. Ser-E. Tor. & sandstones/conglomerates & 183 & 45 & 19 & 17 & 9 & 91 & 89 & 284 & 2 & 192 \\
\hline
\end{tabular}


Tortonian shallow marine and the Late Tortonian-Early Messinian formations and it ended in any case prior to the Late Messinian deposition (fig 4).

Map-scale faults associated with this event together with two extension-parallel geological cross-sections are given in figure $8 . \mathrm{D} 2 \mathrm{~b}$ meso-scale fault systems are less abundant than the previous $\mathrm{D} 1_{\mathrm{b}}$ ones and are particularly localised toward the basin margins (fig. 3). The southern part of the basin, where the depocentre has migrated through time display the most important faults while to the North, the basin basal unconformity is only slightly reworked (fig. 8). Besides, some faults seem to locally reactivate the FSZ, as in eastern Almanzora corridor where fault-bounded blocks carry small half-graben shaped basins (fig. 8). Conversely, in the Albanchez region, the main faults seem to cross-cut the FSZ as the NF rocks are involved in the hanging wall of the Albanchez normal fault (fig. 3 and fig. 8). Two extension-parallel cross-sections are given on figure 8 .

\section{Palaeostress tensor group $\mathrm{D3}_{\mathrm{b}}(\mathrm{N}-\mathrm{S}$ to $\mathrm{NW}-\mathrm{SE}$ shortening)}

The last stage of faulting includes dominantly SW-NE trending sinistral faults, supplemented by scarce NW-SE dextral strike-slip faults (fig. 9, sites 01, 02, 08, 09, 13), and

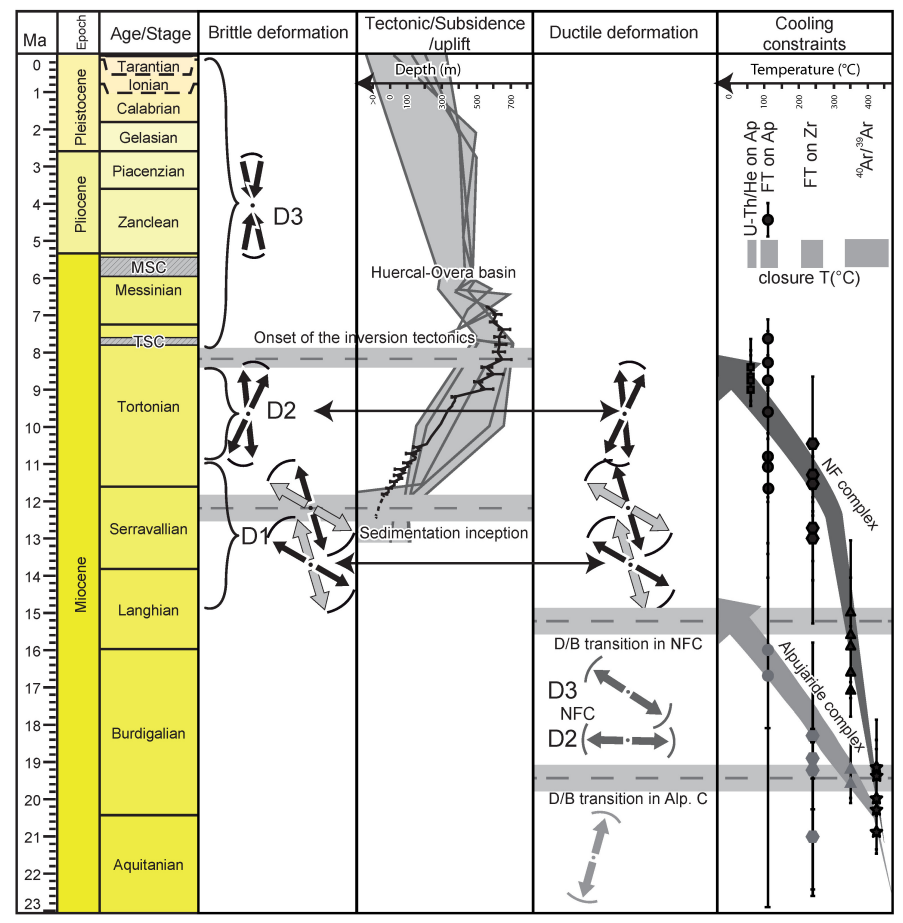

FIG. 10. - Synthetic view of the late- to post-orogenic deformation of the Internal zones metamorphic rocks and their sub-surface expression in the basins. Reminded are the main results of this study and various compilations of exiting results. Solid-black line is a tectonic subsidence curve for the Huércal-Overa basin [Augier, 2004] superimposed on tectonic subsidence curves for other Internal zones basins [Cloething et al., 1992]. Arrows referred to presumed cooling paths during the latest exhumations stages of the Alpujárride and the Nevado-Filábride complexes. Times-constraints are from Platt et al. [2005]; Augier et al. [2005c] for ${ }^{40} \mathrm{Ar} /{ }^{39} \mathrm{Ar}$ analyses [Johnson 1993, 1995; Johnson et al., 1997; Platt et al., 2005; Vázquez et al., 2011] for fission-tracks analyses on zircons and apatites and Vázquez et al. [2011] for U-Th/Pb analyses on apatites. Closure-temperatures are discussed in the text.
E-W to WSW-ENE conjugate sets of reverse faults (fig. 9, sites $01,03,08,09,13,16$,). In most sites, the fault population attributed to this palaeostress tensor group contains a significant amount of reactivated faults planes, in particular, $\mathrm{NW}-\mathrm{SE}$-trending steep planes formed with an initial $\mathrm{D} 1_{\mathrm{b}} \mathrm{ki}$ nematics (fig. 9, sites 04, 13, 41, 46). This event is partly characterised by strike-slip palaeostress tensor solutions with maximum compression direction $\left(\sigma_{1}\right)$ oriented approximately $\mathrm{N}-\mathrm{S}$ and minimum compression direction $\left(\sigma_{3}\right)$ roughly E-W (fig. 9, sites $05,13,41,46$ ). A few stations present compressional palaeostress tensors characterised by a maximum compression direction $\left(\sigma_{1}\right)$ again oriented approximately $\mathrm{N}-\mathrm{S}$ and minimum compression direction $\left(\sigma_{3}\right)$ roughly vertical (fig. 9, sites 08). Other sites present a mixture of this two stress states sharing a common N-S trending maximum compression yielding non-realistic neither vertical nor horizontal intermediate and minimum compression direction. However, field analyses, indicating contradictory cross-cutting relationships argue for an alternation of the two stress fields probably favoured by close absolute values of $\sigma_{2}$ and $\sigma_{3}$. Meso-scale faults associated with this event are dominantly $\mathrm{SW}-\mathrm{NE}$ sinistral faults that often reactivate $\mathrm{D} 1_{\mathrm{b}}$ meso-scale normal faults (fig. 6). The only newlyformed meso-scale $\mathrm{D} 3_{\mathrm{b}}$ compressional structure is located on the southern termination of the Alhama de Murcia fault (fig. 9).

\section{DISCUSSION AND CONCLUSIONS}

\section{The intramontane basins as a record of the latest exhumation stages of the NF rocks}

First clearly stated by Vissers et al. [1995] a close relationship between the exhumation of Alpine metamorphic rocks and the formation of normal fault-bounded intramontane basins has been recently put forward again [Augier, 2004; Augier et al., 2005b; Meijninger and Vissers, 2006]. Intramontane basins would have developed on top of the previously thickened, collapsing Betic-Rif orogenic system affected by pervasive $\sim \mathrm{E}-\mathrm{W}$ back-arc extension driven by the westward roll-back, tearing and local detachments of the subducting plate [e.g. Morley, 1993; Lonergan and White, 1997; Duggen et al., 2003, 2004; Spakman and Wortel, 2004].

However, to date, relationships between the exhumation of Alpine metamorphic rocks and the formation of intramontane basins only rely on the simultaneity of the latest exhumation stages of the NF complex [Johnson, 1993; Johnson et al., 1997; Vázquez et al., 2011] and the deposition of Miocene sediments carrying the first NevadoFilábride detritus [Ruegg, 1964; Kleverlaan, 1989; Briend et al., 1990; Mora, 1993; Poisson et al., 1999; Vissers et al., 1995; Pascual-Molina, 1997; Augier, 2004; Meijninger and Vissers, 2006]. This interpretation is however questioned by the kinematics of the deformation recorded along the FSZ and in the hanging wall unit carrying the basins. Indeed, besides the exhumation related to the intense thinning of the Alpujarride complex, most of the NF complex final exhumation is achieved by a set of major top-to-the-W shear zones [Martínez-Martínez et al., 2002, 2004; Augier et al., 2005b; Agard et al., 2011], while the kinematics of the extensional deformation deduced from the basin analysis has a strong N-S component [e.g. Mora, 1993; Orozco et 
al., 1999; Augier et al., 2005b; Meijninger and Vissers, 2006]. The present structural investigations in both the basement area including a $40 \mathrm{~km}$-long segment of the FSZ and the Almanzora corridor and the Huércal-Overa basins allow proposing a new model for the formation of the basins. Figure 10 provides a compilation of existing kinematics and time-constraints either for the final exhumation stages of both the Alpujarride and the NF complexes or time-markers for the formation and the development of the intramontane basins.

After a consistent top-to-the-west ductile shearing during $\mathrm{D} 2_{\mathrm{d}}$ stage prevailing during most of the decompression of the NF complex and the formation of the main planar-linear fabric (figs 7 and 10), final exhumation stages for the last ca. $10 \mathrm{~km}$ were in turn characterised by important kinematics changes [Augier et al., 2005b]. Indeed, during D $3_{\mathrm{d}}$, the formation of the dome was proposed to explain the divergence of both the stretching lineation and the sense of shear at the scale of the whole Sierra de los Filabres dome limbs (fig. 10 [Augier et al., 2005b]). In the northern Sierra de los Filabres, this study clearly shows the obliquity of the $\mathrm{D} 2{ }_{\mathrm{d}}$ and the $\mathrm{D} 3_{\mathrm{d}}$ stretching lineations (fig. 10). In the uppermost part of the NF complex, into the FSZ mylonites, latest ductile strain increments were thus characterised by NW to NNW stretching lineation associated with a clear top-tothe-NW/NNW sense of shear (fig. 10). Last greenschist mineral recrystallisations occurred at ca. $2 \mathrm{kbar}$ for $\left(350^{\circ} \mathrm{C}\right.$ around $15 \mathrm{Ma}$, locally even as late as $13 \mathrm{Ma}$ [Platt et al., 2005; Augier et al., 2005c]. Exhumation of the NF complex was then completed under brittle conditions by continued motions on the FSZ accompanied by the formation of thick tectonic breccia indicating consistent top-to-the-NW/NNW kinematics. A clear continuum of extensional strain from latest ductile to brittle regime is then observed within the FSZ with common top-to-the-NW/NNW kinematics (figs. 10). Independently, new field mapping on the hanging wall unit highlighted mostly NW-dipping SW-NE trending mesoscale normal fault system that controls the Late SerravallianEarly Tortonian continental formation within large-scale asymmetric troughs (fig. 7 [Pedrera et al., 2009, 2010]). Furthermore, inversion of fault-slip data along of SW-NEtrending normal small-scale faults pertaining to the oldest brittle tectonic event $\left(\mathrm{D} 1_{\mathrm{b}}\right)$ concurrently point to a NW-SE directed subhorizontal extension. It thus appears that the inception of sedimentation occurred shortly after the crossing of the ductile-brittle transition at ca. 14-13 Ma [Augier et al., 2005c] and the onset of cataclastic deformation on the FSZ under an overall SW-NE extensional stress field (fig. 10). The coaxiality of the latest ductile and the subsequent brittle kinematics of the FSZ as well as the consistency between kinematics for the meso-scale fault systems that primarily control the main sedimentation depocentres and the palaeostress tensors deduced from $\mathrm{D} 1_{\mathrm{b}}$ brittle event allow concluding to a continuum of strain during exhumation ultimately responsible for the onset of sedimentation in the basins (fig. 11). The resulting overall architecture of the hanging wall unit is a series of fault-bounded blocks collecting sedimentation (i.e. half-grabens) separated by meso-scale normal faults dipping away from the dome and probably rooting in the FSZ.

Extensional deformation prolonged $\mathrm{D} 2{ }_{\mathrm{b}}$ with different, rather N-S to SW-NE kinematics and therefore lasted during most of the Tortonian times as already described (fig. 10) [Mora, 1993, Meijninger and Vissers, 2006]. D $2_{b}$ deformation stage that partly reactivates $\mathrm{D} 1_{\mathrm{b}}$ faults formed a new set of meso-scale normal faults dominantly located to the South of the basin as exemplified in the Albanchez area where the main fault clearly cut the FSZ and seem to listrically bend down on an intra-NF, shallow North-dipping extensional detachment. Development of the basin therefore appears coeval with the latest exhumation stages of the NF complex settled at ca. 9-8 Ma and subsequently ceased to be active depocentres whereas tectonic denudation of the $\mathrm{Si}$ erra de los Filabres ended (fig. 10) [Johnson et al., 1997; Vázquez et al., 2011]. The Huércal-Overa and the Almanzora corridor basins are thus initially purely extensional basins as already proposed [Mora, 1993; Vissers et al. 1995; Augier et al. 2005b; Meijninger and Vissers, 2006] but this study reveals how the basins developed during the exhumation of the NF complex and sheds lights on the evolution of the FSZ thought time. At larger-scale, an overall half-graben architecture has already been reported based on seismic profiles analysis for the Granada [Morales et al., 1990; Ruano et al., 2004], the Fortuna-Guadalentín basins [Amores et al., 2001; 2002] or in the Alboran sea [Comas et al., 1992, 1999; Mauffret et al., 1992; Watts et al., 1993]. It is also noteworthy that existing compilations of tectonic subsidence of onland basins (fig. 10) [e.g. Cloething et al., 1992] revealed a general common subsidence history from the Late-Serravallian onward. One can then propose that most of these basins initiated as extensional basins linked with the coeval exhumation of the NF complex albeit now sometimes bounded by bounding strike-slip or even reverse faults. This raises the problem of how far this crustal shear zone and particularly the Alhama de Murcia faults played a role in intramontane basin development.

\section{Deciphering the importance of the Trans-Alboran transcurrent zone in the finite strain geometry of the Internal zones}

Strike-slip activity over the major faults of the TransAlboran transcurrent zone has been recognised at least from the (uppermost Tortonian?) Early Messinian to the present [Booth-Rea et al., 2003; Masana et al., 2004] with finite displacements amounting to several tens of kilometres [Weijermars, 1987; Galindo-Zaldívar et al., 1989]. However, the timing of the onset of strike-slip faulting, the nature of the initial movements as well as their importance or their relationships with the development of the intramontane basin are still debated.

New palaeostress analysis showed that extensional brittle deformation developed, at least from the Late Serravallian onward in direct relation with the final exhumation of the NF complex. Having a strong N-S component, kinematics of extensional deformation appear in direct conflict either with the N-S to NW-SE Eurasia/Africa convergence [e.g. Serpelloni et al., 2007] or the inferred current sinistral kinematics of the trans-Alboran transcurrent zone. Conversely, detailed field observations on both small-scale and meso-scale faults showed a polyphased-slip history, with early rather dip-slip, mainly normal motions $\left(\mathrm{D} 1_{\mathrm{b}}\right.$ and $\left.\mathrm{D} 2_{\mathrm{b}}\right)$ overprinted by younger sinistral strike-slip motions $\left(\mathrm{D} 3_{\mathrm{b}}\right)$. Besides, part of the NE-SW trending faults may also have initiated and acted during $\mathrm{D} 2{ }_{\mathrm{b}}$ as extension- 
parallel transfer structures. Consequently, these NE-SW trending faults were formed (or reactivated) in the Early Messinian during $\mathrm{D} 3_{\mathrm{b}}$, hence real strike-slip activity on these faults clearly postdate the development of the intramontane basins. More importantly, the recent interpretation of a NW-SE seismic profile through the Fortuna basin [Amores et al., 2001; Meijninger and Vissers, 2006] suggests that, at least, the Alhama de Murcia fault acted as a NW-dipping growth normal fault controlling the sedimentation of Seravallian-Tortonian series. Conversely, it is therefore tempting to propose an initial normal motion for the NE-SW trending faults such as the Huércal-Overa fault regarded as the southwestern prolongation of the Alhama de Murcia fault [e.g. Montenat et al., 1977; 1999; Pedrera et al., 2007, 2010].

\section{Possible regional consequences for the late orogenic resuming of shortening in the Internal zones}

At variance with the External zones that have recorded shortening since the latest Oligocene Early Miocene [García-Dueñas et al., 1992, Comas et al., 1992; García-Castellanos, 2002], the Internal zones appear subjected to coeval pervasive extensional tectonics. This evolution is a common feature in the Mediterranean realm thus characterised by confined back-arc extensional tectonics in an overall convergent setting. Another fairly widespread feature is the late resuming of shortening within the collapsed hinterlands in accordance with global plate motions [e.g. Dewey et al., 1989; De Mets et al., 1990, 1994; Rosenbaum et al., 2002; Serpelloni et al., 2007].

New structural observations together with palaeostress analysis demonstrated that the area experienced a $\sim \mathrm{N}-\mathrm{S}$ to NNW-SSE compressional stress regime at the end of the development of the basins. The poor structural record of this compressional event in the study area pleads for a rather weak inversion of extensional structures and the architecture of the basins remain basically half-grabens. However, the Huércal-Overa basin clearly recorded a general uplift associated with the reappearance of coarse-grained continental sedimentation after open-marine conditions (fig. 10 [Mora, 1993; Augier, 2004]. While the ultimate tectonic cause of the Late Miocene crises has not yet been clearly identified, it appears clearly that the progressive closure of the western Mediterranean domain is responsible for the limitation of water exchanges with the Atlantic ocean
[Jolivet et al., 2006]. This raises the question of the ability of this resuming of shortening within the Internal Zones in terms of intensity (i.e. shortening/uplift) or timing to reduce Atlantic water supplies and ultimately to trigger salinity crises.

In the southern Huércal-Overa basin, extensional tectonics is sealed by the Late Messinian through a weak angular unconformity. The accurate timing of inversion tectonics remains however uncertain. Besides, space reduction and inception of a major regressive trend in the sedimentation illustrated by a clear shallowing and coarsening upward sequence clearly appear toward the top of the Late TortonianMessinian formation [Pascual-Molina, 1997; Augier, 2004; see also Meijninger, 2006]. In the Vera and Sorbas basins, progressive unconformities (i.e. growth-strata) within the Late Tortonian record were also ascribed to the uplift of the Sierra Alhamilla-Cabrera [Weijeimars, 1987; Barrágan, 1997]. Based on 1D tectonic subsidence analysis, a ca. 8.2 Ma age was thus proposed to reflect the general uplift inferred to the resuming of shortening (fig. 10) [Augier, 2004]. A similar ca. 8 Ma age was already proposed at the scale of the Internal zones when a general uplift affected the basins that consequently ceased to be active depocentres (fig. 10 [see also Cloething et al., 1992]. At the scale of the Internal zones, inversion tectonics resulted in large-scale structures and long-term effects leading to the disconnection of the now emerged basins from the Alboran sea [Comas et al., 1992] and lifting Messinian and Pliocene marine marls up to $1000 \mathrm{~m}$ [Martínez-Martínez et al., 2002]. Recently settled between 7,8 and 7,6 Ma, the Tortonian salinity crisis occurred shortly after the onset of inversion tectonics and may illustrate the inception of basin individualisation favouring local evaporitic events (fig. 10) [Krijgsman et al., 1999b; Garcés et al., 2001; Kuiper et al., 2006]. The Messinian salinity crisis, now precisely dated at 5,96 Ma in the Sorbas basin [i.e. Gautier et al., 1994; Krijgsman et al., 1999a] occurred ca. 2 Ma later, the time needed to stop water exchanges with the Atlantic ocean.

Acknowledgements. - This work was supported by the F.R. CEPAGE and the contribution of the UMR 7193 and the UMR 7327 [CNRS]. We are indebted to the editor O. Lacombe and the invited editor F. Bergerat together with A. Crespo-Blanc and an anonymous reviewer for their constructive reviews that have greatly helped us to improve the manuscript. P. Agard for discussions in the field and J. Angelier for its rough yet so useful and valuable tips for the analysis of the brittle deformation.

\section{References}

Adams G.C., Benson R.H., Kidd R.B., Ryan W.B.F. \& Wright R. C., (1977). - The Messinian salinity crisis and evidence of late Miocene eustatic changes in the world ocean. - Nature, 269 , 383-386.

Agard P., Augier R. \& Monié P. (2011). - Shear band formation and strain localization on a regional scale: Evidence from anisotropic rocks below a major detachment (Betic cordilleras, Spain). - J. Struct. Geol., 33, 114-131.

Amores L.R., Hernandez-Enrile J.L. \& Martínez-Díaz J.J. (2001). Sobre los factores relacionados con la evaluación de la peligrosidad sísmica en la región de Murcia. In: Secundo Congreso Iberoamericano de Ingeniería Sísmica, Madrid, Spain, Asociación Española de Ingeniería Sísmica.
Amores L.R., Hernandez-Enrile J.L. \& Martínez-Díaz J.J. (2002). Estudio gravimétrico previo aplicado a la identificación de fallas ocultas como fuentes sismogenéticas en la depresión del Guadalentín (región de Murcia). - Geogaceta, 32, 307-310.

Anderson E.M. (1942). - The dynamics of faulting. - Oliver and Boyd Editions., Edinburgh.

ANGelier J. (1984). - Tectonic analysis of fault slip data sets. - J. Geophys. Res., 89, 5835-5848.

ANGELIER J. (1990). - Inversion of field data in fault tectonics to obtain the regional stress: a new rapid direct inversion method by analytical means. - Geophys. J. Int., 103, 363-376. 
ANGELIER J. (1994). - Fault slip analysis and palaeostress reconstruction. In: P.L. Hancock, Eds., Continental deformation. - Pergamon Press, Oxford, 53-100.

Augier R. (2004). - Evolution tardi-orogenique des Cordillères bétiques (Espagne): Apports d'une étude intégrée. - Unpublished Thesis, Université Pierre et Marie Curie, Paris, 400p.

Augier R., Booth-Rea G., Agard P., Martínez-Martínez J.M., Jolivet L. \& AZAÑón J.M. (2005a). - Exhumation constraints for the lower Nevado-Filábride complex (Betic Cordillera, SE Spain): a Raman thermometry and Tweequ multiequilibrium thermobarometry approach. - Bull. Soc. géol. Fr, 176, 5, 403-416.

Augier R., Jolivet L. \& Robin \& C. (2005b). - Late Orogenic doming in the eastern Betic cordilleras: Final exhumation of the NevadoFilábride complex and its relation to basin genesis. - Tectonics, 24, TC4003.

Augier R., Agard P., Monié P., Jolivet L., Robin C. \& Booth-Rea G. (2005c). - Exhumation, doming and slab retreat in the Betic cordillera (SE Spain): in situ ${ }^{40} \mathrm{Ar} /{ }^{39} \mathrm{Ar}$ ages and P-T-d-t paths for the Nevado-Filábride complex. - J. metam. Geol., 23, 357-381.

AZAÑón J.M. \& Goffé B. (1997). - Ferro-magnesiocarpholite-kyanite assemblages as record of the high-pressure, low-temperature metamorphism in central Alpujárride units, Betic cordillera (SE Spain). - Eur. J. Mineral., 9, 1035-1051.

AzAÑón J.M. \& CRespo-BlanC A. (2000). - Exhumation during a continental collision inferred from the tectonometamorphic evolution of the Alpujárride complex in the central Betics (Alboran domain, SE Spain). - Tectonics, 19, 3, 549-565.

Azañón J. M., García-Dueñas V., Martínez-Martínez J.M. \& Crespo Blanc A. (1994). - Alpujárride tectonic sheets in the central Betics and similar eastern allochthonous units (SE Spain). $-C$. $R$. Acad. Sci., Paris, 318, II, 667-674.

Azañón J. M., García-Dueñas V. \& GofFe B. (1998). - Exhumation of high-pressure metapelites and coeval crustal extension in the Alpujárride complex (Betic cordillera). - Tectonophysics, 285, 3-4, 231-252.

Bache F., Popescu S.M., Rabineau M., Gorini C., Suc J.-P., Clauzon G., J-L. Olivet, Rubino J.-L., Melinte-Dobrinescu M. C., Estrada F., Londeix L., Armijo R., Meyer B., Jolivet L., Jouannic G., Leroux E., Aslanian D., Reis T. D., Mocochain L., Dumurdžanov N., Zagorchev I., Lesic V., Tomic D., ÇagataY M.N., Brun J.-P., Sokoutis D., Csato I., Ucarkus G. \& Çakir Z. (2011). - A two-step process for the reflooding of the Mediterranean after the Messinian salinity crisis. - Basin Res., doi: 10.1111/j.1365-2117.2011.00521.x.

BARRAGÁN G. (1997). - Evolución geodinámica de la depresión de Vera. Doctoral, Universidad de Granada, 300pp.

Booth-Rea G., Azañón J. M., García-Dueñas V. \& Augier R. (2003). Uppermost Tortonian to Quaternary depocentre migration related with segmentation of the strike-slip lomares Pafault zone, Vera basin (SE Spain). - C. R. Geoscience, 335, 9, 751-761.

BousqueT J.-C. (1979). - Quaternary strike-slip faults in southeastern Spain. - Tectonophysics, 52, 277-286.

Bousquet J.-C. \& Montenat C. (1974). - Présence de décrochements nord-est - sud-ouest plio-quaternaires, dans les Cordillères bétiques orientales (Espagne). Extension et signification générale. C. R. Acad. Sci., Paris, 278, D, 2617-2620

Bousquet J.-C., Dumas B. \& Montenat C. (1975). - Le décrochement de Palomarès: décrochement quaternaire senestre du bassin de Vera (Cordillères bétiques orientales. Espagne). - Cuad. Geol. Univ. Granada, 6, 113-119.

BRIEND M. (1981). - Evolution morpho-tectonique du bassin néogène de Huercal-Overa (Cordillères bétiques orientales, Espagne). Doc. Trav. IGAL, 4, Paris, 208 p.

Briend M., Montenat C. \& Ott D’Estevou P. (1990). - Le bassin de Huercal-Overa. In: C. Montenat, Ed., Les bassins néogenes du domaine bétique oriental (Espagne). - Doc. Trav. IGAL, 12-13, 239-259.

CAREY E. \& Brunier B. (1974). - Analyse théorique et numérique d'un modèle mécanique élémentaire appliquée à l'étude d'une population de failles. - C. R. Acad. Sci., Paris D, 279, 891-894.

Cloething S., Beek P.A. v.D., Rees D.v., Roep T.B., Biermann C. \& StePHENSON R. (1992). - Flexural interaction and the dynamics of Neogene extensional basin formation in the Alboran-Betic region. - Geo-Mar. Lett., 12, 66-75.
Comas M.C., García-Dueñas V. \& Jurado M.J. (1992). - Neogene tectonic evolution of the Alboran sea from MCS data. - Geo-Mar. Lett., 12, 2, 157-164.

Comas M.C., Platt J.P., Soto J.I. \& Watts A.B. (1999). - The origin and tectonic history of the Alboran basin: insights from leg $161 \mathrm{re}$ sults. - Ocean Drill. Progr., 161, 555-580.

CRESPO-BlanC A. (1995). - Interference pattern of extensional fault systems: a case study of the Miocene rifting of the Alboran basement (north of Sierra Nevada, Betic chain). - J. Struct. Geol., 17, 11, 1559-1569.

Crespo-Blanc A., Orozco M. \& García-Dueñas V. (1994). - Extension versus compression during the Miocene tectonic evolution of the Betic chain. Late folding of normal fault systems. - Tectonics, 13, 78-88.

De Jong K. \& BAKKer H. (1991). - The Mulhacen and Alpujárride complex in the eastern Sierra de los Filabres, SE Spain: Lithostratigraphy. - Geol. Mijnb., 70, 93-103.

DE JoNG K. (2003). - Very fast exhumation of high-pressure metamorphic rocks with excess ${ }^{40} \mathrm{Ar}$ and inherited ${ }^{87} \mathrm{Sr}$, Betic Cordilleras, southern Spain. - Lithos, 70, 91-110.

De Larouzière F.D.D., Bolze J., Hernandez J., Montenat C. \& D’EsteVou P. O. (1988). - The Betic segment of the lithospheric Trans-Alboran shear zone during the Late Miocene. - Tectonophysics, 152, 41-52.

De Mets C., Gordon R.G., Argus D.F. \& Stein S. (1990). - Current plate motions. - Geophys. J. Int., 101, 425-478.

Dewey J.F., Helman M.L., Torco E., Hutton D.H.W. \& Knott S.D. (1989). - Kinematics of the western Mediterranean. In: M.P. Coward, D. Dietrich and R.G. PARK, Eds., Alpine tectonics. Geol. Soc. Spec. Pub., 45, 265-283.

Doblas M. (1998). - Slickenside kinematic indicators. - Tectonophysics, 295, 187-197.

Duggen S., Hoernle K., Bogaard P. v.D., RüPke L. \& Morgan J.P. (2003). - Deep roots of the Messinian salinity crisis. - Nature, 422, 602-606.

Duggen S., Hoernle K., Bogaard P. v.D. \& Harris C. (2004). - Magmatic evolution of the Alboran region: The role of subduction in forming the western Mediterranean and causing the Messinian salinity crisis. - Earth Planet. Sci. Lett., 218, 91-108.

Egeler C.G. \& Simon O.J. (1969). - Sur la tectonique de la zone bétique (Cordillères bétiques, Espagne). Étude basée sur la recherche dans le secteur compris entre Almería y Vélez Rubio. - Verh. Kon. Ned. Akad. Wet. Afd. Natuurk., 25, 1-90.

Faccenna C., Piromallo C., Crespo-Blanc A., Jolivet L. \& Rossetti F. (2004). - Lateral slab deformation and the origin of the western Mediterranean arcs. - Tectonics, 23, TC1012, doi: 10.1029/ 2002 TC001488.

FRY N. (1992). - Stress ratio determinations from striated faults: a spherical plot for cases of near-vertical principal stress. - J. Struct. Geol., 10, 1121-1131.

FRY N. (1999). - Striated faults: visual appreciation of their constraint on possible palaeostress tensors. - J. Struct. Geol., 21, 7-21.

Galindo-Zaldívar J., GonZÁlez-Lodeiro F. \& Jabaloy A. (1989). - Progressive extensional shear structures in a detachment contact in the western Sierra Nevada (Betic cordilleras, Spain). - Geodin. Acta, 3, 73-85.

García-Castellanos D. (2002). - Interplay between lithospheric flexure and river transport in foreland basins. - Basin Res., 14, 89-104.

García-Dueñas V., Balanyá J.C. \& Martínez-Martínez J.M. (1992). Miocene extensional detachments in the outcropping basement of the northern Alboran basin (Betics) and their tectonic implications. - Geo-Mar. Lett., 12, 88-95.

García-Meléndez E., Goy J.L. \& Zazo C. (2003). - Neotectonics and Plio-Quaternary landscape development within the eastern Huercal-Overa basin (Betic Cordilleras, Southeast Spain). - Geomorphology, 50, 111-133.

García-Monzón G. \& Kampschuur W. (1975). - Mapa geológico de España, E: 1: 50,000; Hoja 1014, Vera. - Instituto Geológico y Minero de España (IGME), Minist. de Ind. y Energia, Madrid.

García-Monzón G., Kampschuur W. \& Vissers R.L.M. (1975). - Mapa geológico de España, E: 1: 50,000; Hoja 1013, Macael. - Instituto Geológico y Minero de España (IGME), Minist. de Ind. y Energia, Madrid. 
Garcés M., Krijgsman W. \& Agusti J. (2001). - Chronostratigraphic framework and evolution of the Fortuna basin (eastern Betics) since the late Miocene. - Basin Res., 13, 199-216.

Gautier F., Clauzon G., Suc J.-P., Cravatte J. \& Violanti D. (1994). Age et durée de la crise de salinité messinienne. - C.R. Acad. Sci., Paris, 318, 2, 1103-1109.

Goffé B., Michard A., García-Dueñas V., González-Lodeiro F., Monié P., Campos J., Galindo-Zaldívar J., Jabaloy A., Martínez MARTíneZ J.M. \& SimAnCAS F. (1989). - First evidence of high-pressure, low-temperature metamorphism in the Alpujárride nappes, Betic cordillera (SE Spain). - Eur. J. Miner., 1, 139-142.

Gómez-Pugnaire M.T. \& Fernández-Soler J.M. (1987). - High-Pressure metamorphism in metabasite from the Betic cordilleras (SE Spain) and its evolution during the Alpine orogeny. - Contrib. Mineral. Petrol., 95, 231-244.

González-Casado J.M., Casquet C., Martínez-Martínez J.M. \& GarC ÍA-DUEÑAS V. (1995). - Retrograde evolution of quartz segregations from the Dos Picos shear zone in the Nevado-Filábride complex (Betic chains, Spain). Evidence from fluid inclusions and quartz c-axis fabrics. - Geol. Rundsch., 84, 175-186.

Guerra-Merchán A. \& Serrano F. (1993). - Tectonosedimentary setting and chronostratigraphy of the Neogene reefs in the Almanzora corridor (Betic Cordillera, Spain). - Geobios, 26, 57-67.

Guerra-Merchán A., Ramallo D. \& Ruiz-Bustos A. (2001). - New data on the Upper Miocene micromammals of the Betic cordillera and their interest for marine continental correlations. - Geobios, 34, 85-90

HANCOCK P.L. (1985). - Brittle microtectonics: principles and practice. J. Struct. Geol., 7, 3/4, 437-457.

Hardcastle K.C. \& Hills L.S. (1991). - BRUTE3 and SELECT: Quickbasic 4 programs for determination of stress tensor configurations and separation of homogeneous populations of fault-slip data. Computers \& Geosci., 17, 23-43.

Hodell D.A., Elmstron K.M. \& Kennett J.P. (1986). - Latest Miocene benthic $\left({ }^{18} \mathrm{O}\right.$ changes, global ice volume, sea level and the "Messinian salinity crisis". - Nature, 320, 3, 411-414.

Jabaloy A., Galindo-Zaldívar J. \& GonZÁlez-Lodeiro F. (1993). - The Alpujárride-Nevado-Filábride extensional shear zone, Betic cordillera, SE Spain. - J. Struct. Geol., 15, 3-5, 555-569.

Johnson C.J. (1993). - Contrasted thermal histories of different nappe complexes in SE Spain: evidence for complex crustal extension. In: M. SÉranne, J. Malavieille, Eds., Late orogenic extension in mountain belts. - Doc. BGRM, 209.

Johnson C.J. (1995). - Neogene tectonics in SE Spain: constraints from FT analysis. - PhD thesis, University of London, 298 pp

Johnson C.J., HARBURY N. \& HuRford A.J. (1997). - The role of extension in the Miocene denudation of the Nevado-Filábride complex, Betic cordillera (SE Spain). - Tectonics, 16, 2, 189-204.

Jolivet L. \& FACCEnNA C. (2000). - Mediterranean extension and the Africa-Eurasia collision. - Tectonics, 19, 6, 1095-1106.

Jolivet L., Augier R., Robin C., Suc J.-P. \& Rouchy J.-M. (2006). - Lithospheric-scale geodynamic context of the Messinian salinity crisis. - Sedim. Geol., 188-189, 9-33.

Kleinspehn K.L., Pershing J. \& Teyssier C. (1989). - Palaeostress stratigraphy: A new technique for analyzing tectonic control on sedimentary-basin subsidence. - Geology, 17, 3, 253-256.

KleverlaAn K. (1989). - Neogene history of the Tabernas basin (SE Spain) and its Tortonian submarine fan development. - Geol. Mijnb., 68, 421-432.

Krijgsman W., Hilgent F.J., Raffi I., Sierro F.J. \& Wilson D.S. (1999a). Chronology, causes and progression of the Messinian salinity crisis. - Nature, 400, 652-655.

Krijgsman W., Langereis C.G., Zachariasse W.J., Boccaletti M. Moratti G., Gelati R., Iaccarino S., Papani G. \& Villa G. (1999b). - Late Neogene evolution of the Taza-Guercif basin (Rifian corridor, Morocco) and implications for the Messinian salinity crisis. - Mar. Geol., 153, 147-160.

Krijgsman W., Garcés M., Agusti J., Raffi I., Taberner C. \& ZachaRIASSE W. J. (2000). - The 'Tortonian salinity crisis' of the eastern Betics (Spain). - Earth Planet. Sci. Lett., 181, 497-511.

Kuiper K.F., KriJgsman W., Garcés M. \& WiJbrans J.R. (2006). - Revised isotopic $\left({ }^{40} \mathrm{Ar} /{ }^{39} \mathrm{Ar}\right)$ age for the lamproite volcano of Cabezos Negros, Fortuna basin (eastern Betics, SE Spain). Palaeogeogr., Palaeoclimatol., Palaeoecol., 238, 1-4, 53-63.
Leblanc D. \& Olivier P. (1984). - Role of strike-slip faults in the Betic-Rifian orogeny. - Tectonophysics, 101, 345-355.

LiSLE R.J. (1987). - Principal stress orientations from faults: an additional constraint. - Ann. Tecton., 1, 155-158.

LisLE R.J. (1988). - Romsa: a basic program for palaeostress analysis using fault-striation data. - Computers \& Geosciences, 14, 255-259.

LONERGan L. \& PlatT J.P. (1995). - The Malaguide-Alpujárride boundary: a major extensional contact in the internal zones of the eastern Betic cordillera, SE Spain. - J. Struct. Geol., 17, 1655-1671.

LONERGAN L. \& WHITE N. (1997). - Origin of the Betic-Rif mountain belt. Tectonics, 16, 3, 504-522.

López Sánchez-Vizcaíno V., Rubatto D., Gómez-Pugnaire M.T., TrommSDORFF V. \& MÜntener O. (2001). - Middle Miocene high-pressure metamorphism and fast exhumation of the NevadoFilábride complex, SE Spain. - Terra Nova, 13, 327-332.

Luján M., CRespo-Blanc A. \& Comas M. (2011). - Morphology and structure of the Camarinal sill from high-resolution bathymetry: evidence of fault zones in the Gibraltar strait. - Geo-Mar. Lett., 31-3, 163-174.

Maloney D., Davies R., Imber J., Higgins S. \& King S. (2010). - New insights into deformation mechanisms in the gravitationally driven Niger delta deep-water fold and thrust belt. - AAPG Bull., 94, 9, 1401-1424.

Martín-PÉrez A. (1997). - Nannoplancton calcáreo del Mioceno de la Cordillera Bética (sector oriental). - Ph.D. Thesis, Universidad de Granada, 452 p.

Martinez-Diaz E. (2002). - Stress field variation related to fault interaction in a reverse oblique-slip fault: the Alhama de Murcia fault, Betic Cordillera, Spain. - Tectonophysics, 356, 291-305.

Martínez-Martínez J.M. \& AzAÑón J.M. (1997). - Mode of extensional tectonics in the southeastern Betics (SE Spain). Implications for the tectonic evolution of the peri-Alboran orogenic system. Tectonics, 16, 2, 205-225.

Martínez-Martínez J.M., Soto J.I. \& Balanyá J.C. (2002). - Orthogonal folding of extensional detachments: structure and origin of the Sierra Nevada elongated dome (Betics, SE Spain). - Tectonics, 21, doi 10.1029/2001TC001283.

Martínez-Martínez J.M., Soto J.I. \& Balanya J.C. (2004). - Elongated domes in extended orogens: A mode of mountain uplift in the Betics (Southeast Spain). In: D. Whitney, C. TEYssiER and C.S. Siddoway, Eds., Gneiss domes in orogeny. - Geol. Soc. Amer., Sp. paper, 380, 243-266.

Masana E., Martínez-Díaz J.J., Hernández-Enrile J.L. \& Santanach P. (2004). - The Alhama de Murcia fault (SE Spain), a seismogenic fault in a diffuse plate boundary: Seismotectonic implications for the Ibero-Magrebian region. - J. Geophys. Res., 109, B1, B01301.

Masana E., Pallàs R., Perea H., Ortuño M., Martínez-Díaz J.J., GarCÍA-Meléndez E. \& Santanach P. (2005). - Large Holocene morphogenic earthquakes along the Albox fault, Betic Cordillera, Spain. - J. Geodyn., 40, 2-3, 119-133.

Mauffret A., Maldonado A. \& Campillo A. C. (1992). - Tectonic framework of the eastern Alboran and western Algerian basins, western Mediterranean. - Geo-Mar. Lett., 12, 2, 104-110.

Meijninger B.M.L. (2006). - Late-orogenic extension and strike-slip deformation in the Neogene of southeastern Spain. - PhD Thesis, Univ. Utrecht. - Geol. Ultraiech., 269, 179 p.

Meijninger B.M.L. \& Vissers R.L.M. (2006). - Miocene extensional basin development in the Betic cordillera, SE Spain revealed through analysis of the Alhama de Murcia and Crevillente faults. - Basin Res., 18, 4, 547-571.

Michard A., Negro F., Saddiei O., Bouybaouene M.L., Chalouan A., Montigny R. \& Goffé B. (2006). - Pressure-temperature-time constraints on the Maghrebide mountain building: evidence from the Rif-Betic transect (Morocco, Spain), Algerian correlations, and geodynamic implications. - C. R. Geoscience, 338, 92-114.

Monié P., Galindo-Zaldívar J., González-Lodeiro F., Goffé B. \& JabALOY A. (1991). $-{ }^{40} \mathrm{Ar} /{ }^{39} \mathrm{Ar}$ geochronology of Alpine tectonism in the Betic cordilleras (southern Spain). - J. Geol. Soc. London, 148, 288-297.

Monié P., Torres-Roldán R.L. \& García-Casco A. (1994). - Cooling and exhumation of the western Betic cordilleras, ${ }^{40} \mathrm{Ar} /{ }^{39} \mathrm{Ar}$ thermochronological constraints on a collapsed terrane. - Tectonophysics, 238, 353-379. 
Montenat C. (1977). - Les bassins néogènes du levant d'Alicante et de Murcie (Cordillères bétiques orientales, Espagne). Stratigraphie, paleogéographie et évolution dynamique. - Doc. Lab. Geol. Fac Sc. Lyon, 69, 345 p.

Montenat C. \& OtT D'Estevou P. (1999). - The diversity of late Neogene sedimentary basins generated by wrench faulting in the eastern Betics cordillera, SE Spain. - J. Petrol. Geol., 22, 1, 61-80.

MorA M. (1993). - Tectonic and sedimentary analysis of the Huercal-Overa region, SE Spain, Betic cordillera. - Oxford University, Oxford England, 300 p.

Morales J., Vidal F., De Miguel F., Alguacil G., Posadas A.M., Ibanez J.M., Guzman A. \& Cuirao J.M. (1990). - Basement structure of the Granada basin, Betic cordilleras, southern Spain. - Tectonophysics, 177, 337-348.

Morley C.K. (1993). - Discussion of origins of hinterland basins to the Rif-Betic cordillera and Carpathians. - Tectonophysics, 226, 359-376.

Orozco M., Molina J.M., Crespo-Blanc A. \& Alonso-Chaves F.M. (1999). - Paleokarst and grauhwacke development, mountain uplift and subaerial sliding of tectonic sheets (northern Sierra de los Filabres, Betic cordilleras, Spain). - Geol. Mijnb., 78, 103-117.

Otт D’Estevou P.O. \& Montenat C. (1990). - Le bassin de Sorbas - Tabernas. In: C. Montenat, Ed., Les bassins néogenes du domaine bétique oriental (Espagne). - Doc. Trav. IGAL, 12-13, 101-128.

Pascual-Molina A.M. (1997). - La cuenca Neógena de Tabernas (Cordilleras béticas). - Doctoral, Universidad de Granada, Granada, $345 \mathrm{p}$.

Pedrera A., Galindo-Zaldívar J., Galdeano C.S. D. \& Lopez-Garrido A.G. (2007). - Fold and fault interactions during the development of an elongated narrow basin: The Almanzora NeogeneQuaternary corridor (SE Betic cordillera, Spain). - Tectonics, 26, doi: 10.1029/2007TC002138.

Pedrera A., Galindo-Zaldívar J., Ruíz-Constán A., Duque C., MarínLechado C. \& Serrano I. (2009). - Recent large fold nucleation in the upper crust: Insight from gravity, magnetic, magnetotelluric and seismicity data (Sierra de Los Filabres-Sierra de Las Estancias, Internal zones, Betic cordillera). - Tectonophysics, 463, 145-160.

Pedrera A., Galindo-Zaldívar J., Tello A. \& Marín-Lechado C (2010). - Intramontane basin development related to contractional and extensional structure interaction at the termination of a major sinistral fault: The Huércal-Overa basin (eastern Betic cordillera). - J. Geodyn., 49, 271-286.

Pedrera A., Galindo-Zaldívar J., Lamas F. \& Ruiz-Constán A. (2012). Evolution of near-surface ramp-flat-ramp normal faults and implication during intramontane basin formation in the eastern $\mathrm{Be}$ tic cordillera (the Huércal-Overa basin, SE Spain). - Tectonics, 31, doi: 10.1029/2012TC003130.

Platt J.P. (1979). - Extensional crenulation cleavage. - J. Struct. Geol., 1, 95.

Platt J.P. (1984). - Secondary cleavages in ductile shear zones. - J. Struct. Geol., 6, 439-442.

Platt J.P. (1986). - Dynamics of orogenic wedges and the uplift of highpressure metamorphic rocks. - Geol. Soc. Amer. Bull., 97, 1037-1053.

Platt J.P. \& VisSERS R.L.M. (1989). - Extensional collapse of thickened continental lithosphere: A working hipothesis for the Alboran sea and Gibraltar arc. - Geology, 17, 540-543.

Platt J.P., Soto J.I., Whitehouse M.J., Hurford A.J. \& Kelley S.P. (1998). - Thermal evolution, rate of exhumation, and tectonic significance of metamorphic rocks from the floor of the Alboran extensional basin, western Mediterranean. - Tectonics, 17, 5, 671-689.

Platt J.P., Kelley S.P., Carter A. \& Orozco M. (2005). - Timing of tectonic events in the Alpujárride complex, Betic cordillera, southern Spain. - J. Geol. Soc., London, 162, 1-12.

Platt J.P., Anczkiewicz R., Soto J.I., Kelley S.P. \& Thirlwall M. (2006). - Early Miocene continental subduction and rapid exhumation in the western Mediterranean. - Geology, 34, 11, 981-984.

Platzman E.S. \& Platt J.P. (2004). - Kinematics of a twisted core complex: Oblique axis rotation in an extended terrane (Betic cordillera, southern Spain). - Tectonics, 23, 6, TC6010.
Poisson A.M., Morel J.L., Andrieux J., Coulon M., Wernli R. \& GuerNET C. (1999). - The origin and development of neogene basins in the SE Betic cordillera (SE SPain): A case study of the Tabernas-Sorbas and Huercal-Overa basins. - J. Petrol. Geol., 22, 1, 97-114.

Puga E., Díaz de Federico A. \& Nieto J.M. (2002). - Tectonostratigraphic subdivision and petrological characterisation of the deepest complexes of the Betic zone: a review. - Geodin. Acta, 15, 23-43.

Reicherter K.R. \& Reiss S. (2001). - The Carboneras fault zone (southeastern Spain) revisited with ground penetrating radar Quarternary structural styles from high-resolution images. - Geol. Mijnb., 80, 129-138.

Rosenbaum G., Lister G.S. \& Duboz C. (2002). - Reconstruction of the tectonic evolution of the western Mediterranean since the Oligocene. In: G. Rosenbaum and G.S. Lister, Eds., Reconstruction of the evolution of the Alpine-Himalayan orogen. - J. Virtual Expl., 8, 107-126.

ROYDEN L.H. (1993). - Evolution of retreating subduction boundaries formed during continental collision. - Tectonics, 12, 3, 629-638.

RuAno P. \& Galindo-Zaldívar J. (2004). - Striated and pitted pebbles as palaeostress markers: an example from the central transect of the Betic cordillera (SE Spain). - Tectonophysics, 379, 183-198.

RUEGG G. (1964). - Geologische onderzoekingen in het bekken van Sorbas, S Spanje. - Amsterdan Geological Institute, Univ. of Amsterdan, $64 \mathrm{p}$.

Sanz de Galdeano C. \& Vera J.A. (1992). - Stratigraphic record and palaeogeographical context of the Neogene basins in the Betic cordillera, Spain. - Basin Res., 4, 1, 21-36.

Serpelloni E., Vannucci G., Pondrelli P., Argnani A., Casula G., AnziDEI M., BAldi B. \& Gasperini P. (2007). - Kinematics of the western Africa-Eurasia plate boundary from focal mechanisms and GPS data. - Geophys. J. Internat., 169, 3, 1180-1200.

SERrano F. (1990). - El Mioceno medio en el area de Nijar (Almeria, Espana). - Rev. Soc. Geol. Espana, 3, (1-2), 65-77.

Serrano F., Galdeano C.S.D., Kadiri K.E., Guerra-Merchan A., Garrido A. C.L., Martin-Martin M. \& Hlila R. (2006). - Oligocene-early Miocene transgressive cover of the Betic-Rif internal zone. Revision of its geologic significance. - Eclogae Geol. Helv., 99, 237-253.

Serrano F., Guerra-Merchan A., Kadiri K. E., Galdeano C.S.D., Gar Rido A.C.L., Martin-Martin M. \& Hlila R. (2007). - Tectono-sedimentary setting of the Oligocene-early Miocene deposits on the Betic-Rifian internal zone (Spain and Morocco). - Geobios, 40, 191-205.

Silva P.G., Goy J.L., Zazo C., Lario J. \& Bardaji T. (1997). - Paleoseismic indications along aseismic fault segments in the Guadalentín depression (SE Spain). - J. Geodyn., 24, 1-4, 105-115.

Simón O.J., Martín-García L. \& Gómez-Prieto J.A. (1978). - Mapa geológico de España E: 1: 50,000; Hoja 995, Cantoria. - Instituto Geológico y Minero de España (IGME), Minist. de Ind. y Energia, Madrid.

Soler R., Masana E. \& Santanach P. (2003). - Evidencias geomorfológicos y estructurales del levantamiento tectónico reciente debido al movimiento inverso de la terminación sudoccidental de la falla de Alhama de Murcia (Cordillera bética oriental). - Rev. Soc. Geol. España, 16, 123-134.

Spakman W. \& Wortel R. (2004). - A tomographic view on western Mediterranean geodynamics. In: W. CAVAzZA, F.M. Roure, W. Spakman, G.M. Stampfli and P. A. Ziegler, Eds., The TRANSMED atlas. - The Mediterranean region from crust to Mantle. - Springer, Heidelberg, 31-52.

Stich D., Ammon C.J. \& Morales J. (2003). - Moment tensor solutions for small and moderate earthquakes in the Ibero-Maghreb region. - J. Geophys. Res., 108, B3, 2148, doi: 10.1029/2002 JB002057.

Tent-Manclús J.E., Soria J.M., Estévez A., Lancis C., Caracuel J.E., DinARES-Turell J. \& Yébenes A. (2008). - The Tortonian salinity crisis in the Fortuna basin (southeastern Spain): Stratigraphic record, tectonic scenario and chronostratigraphy. - C.R. Geosciences, 340, 474-481.

VANDYCKE S. \& BERGERAT F. (2001). - Brittle structures tectonic structures and palaeostress analysis in the isle of Wight, Wessex basin, southern U.K. - J. Struct. Geol., 23, 393- 406. 
VÁzquez M., Jabaloy A., Barbero L. \& Stuart F.M. (2011). - Deciphering tectonic- and erosion-driven exhumation of the NevadoFilábride complex (Betic cordillera, southern Spain) by low temperature thermochronology. - Terra Nova, 23, 4, 257-263.

Vissers R.L.M., Platt J.P. \& VAN DER Wal D. (1995). - Late orogenic extension of the Betic cordillera and the Alboran domain: a lithospheric view. - Tectonics, 14, 4, 786-803.

Voersmans F.M., Simón O.J. \& Martín-García L. (1980). - Mapa geológico de España E: 1: 50000; Hoja 996, Huércal-Overa. - Instituto Geológico y Minero de España (IGME), Minist. de Ind. y Energia, Madrid.
Watts A.B., Platt J.P. \& Buhl P. (1993). - Tectonic evolution of the Alboran Sea basin. - Basin Res., 5, 153-177.

Weijermars R. (1987). - The Palomares brittle-ductile shear zone of southern Spain. - J. Struct. Geol., 9, 2, 139-157.

WeIJERMARS R. (1988). - Neogene tectonics in the western Mediterranean may have caused the Messinian salinity crisis and an associated glacial event. - Tectonophysics, 148, 211-219.

WORTEL M.J.R. \& SPAKMAN W. (2000). - Subduction and slab detachment in the Mediterranean-Carpathian region. - Science, 290, 1910-1917.

ŽALOHAR J. \& VRABEC M. (2007). - Palaeostress analysis of heterogeneous fault-slip data: the Gauss method. - J. Struct. Geol., 29, 1798-1810. 